\title{
South Asian Medicinal Compounds as Modulators of Resistance to Chemotherapy and Radiotherapy
}

\author{
N. Rajendra Prasad ${ }^{1, *}$, Ganesan Muthusamy ${ }^{1}$, Mohana Shanmugam ${ }^{1}$ and \\ Suresh V. Ambudkar ${ }^{2, *}$ \\ 1 Department of Biochemistry and Biotechnology, Annamalai University, Annamalainagar Tamilnadu 608002, \\ India; janakganesh@gmail.com (G.M.); mohanabiogene@gmail.com (M.S.) \\ 2 Laboratory of Cell Biology, Center for Cancer Research, National Cancer Institute, NIH, \\ Bethesda, MD 20892, USA \\ * Correspondence: drprasadnr@gmail.com (N.R.P.); ambudkar@helix.nih.gov (S.V.A.); \\ Tel.: +1-301-402-4178 (S.V.A.)
}

Academic Editor: Zhe-Sheng (Jason) Chen

Received: 18 January 2016; Accepted: 29 February 2016; Published: 5 March 2016

\begin{abstract}
Cancer is a hyperproliferative disorder that involves transformation, dysregulation of apoptosis, proliferation, invasion, angiogenesis and metastasis. During the last 30 years, extensive research has revealed much about the biology of cancer. Chemotherapy and radiotherapy are the mainstays of cancer treatment, particularly for patients who do not respond to surgical resection. However, cancer treatment with drugs or radiation is seriously limited by chemoresistance and radioresistance. Various approaches and strategies are employed to overcome resistance to chemotherapy and radiation treatment. Many plant-derived phytochemicals have been investigated for their chemo- and radio-sensitizing properties. The peoples of South Asian countries such as India, Pakistan, Sri Lanka, Nepal, Bangladesh and Bhutan have a large number of medicinal plants from which they produce various pharmacologically potent secondary metabolites. The medicinal properties of these compounds have been extensively investigated and many of them have been found to sensitize cancer cells to chemo- and radio-therapy. This review focuses on the role of South Asian medicinal compounds in chemo- and radio-sensitizing properties in drug- and radio-resistant cancer cells. Also discussed is the role of South Asian medicinal plants in protecting normal cells from radiation, which may be useful during radiotherapy of tumors to spare surrounding normal cells.
\end{abstract}

Keywords: South Asian plants; ABC transporter; chemoresistance; radioresistance; phytochemicals

\section{Introduction}

The plant kingdom plays an essential role in the life of humans and animals. South Asia is one of the largest producers of medicinal plants and natural products for human health and disease [1]. South Asian countries such as India, Pakistan, Sri Lanka, Nepal, Bangladesh and Bhutan have a large number of plants that are used to produce medicinal agents. In particular, India is one of the largest producers of medicinal plants and can rightly be called the "Botanical Garden of the World". In India, there are about 400 families and 8000 species of medicinal plants, which include approximately $50 \%$ of all the higher flowering plant species [2].

South Asian medicinal plants and their compounds have a very long history of use for cancer treatment. The climate, environment and geography of South Asian countries enable the growth of diverse medicinal plants with novel secondary active compounds, which has attracted the attention of the scientific community. In this review, we focus on the chemosensitizing and radiosensitizing potential of bioactive compounds from South Asian medicinal plants commonly found in Bangladesh, India, Nepal, Pakistan and Sri Lanka, and discuss their mechanisms of action. The chemoprotective 
properties of South Asian plants have been well documented in the literature [3,4]. The plants and their active compounds intercept carcinogenic pathways at various molecular points and prevent carcinogenesis [5]. Furthermore, South Asian medicinal plants and their compounds have been found to exhibit anticancer properties in different experimental models [6,7]. In fact, anticancer properties of South Asian plants have been recognized for centuries. The active compounds isolated from the plants induce apoptotic signaling in certain cancer cell lines [8-16]. For instance, the anticancer property of Abrus precatorius has been reported in regard to fibrosarcomas in mice and ascites tumor cells [17]. South Asian plants that have shown anticarcinogenic properties include the anticancer properties of Albizzia lebbeck concerning stomach carcinoma in humans [6], Asparagus racemosa in human epidermoid carcinoma, Picrorrhiza kurroa in hepatic cancers, Boswellia serrata in human epidermal carcinoma of the nasopharynx, Peaderia foetida in human epidermoid carcinoma of the nasopharynx [18], and Withania somnifera in various tumors [19].

Bioactive compounds isolated from South Asian medicinal plants have drawn much attention from researchers, clinicians, and the general public because of their biologic and pharmacologic properties. The plants are excellent sources of macronutrients (carbohydrates, proteins, fats and fiber) and micronutrients (antioxidants, vitamins and trace minerals). In addition, they are the source of an amazing diversity of secondary metabolites (phytochemicals), which are not essential for normal bodily function but are still biologically active and of medicinal value. Phytochemicals found in South Asian plants can be classified into various families such as alkaloids, flavonoids, isoflavones, isothiocyanates, organosulfur compounds, capsaicinoids and phytosterols, which are chiefly found in coloured, leafy vegetables, yellow/orange fruits and some pungent vegetables such as onion and garlic. Many of these compounds have proven chemopreventive properties [20] and their active ingredients are being studied extensively for their antitumor activity. Further, the active components of South Asian medicinal plants possess radioprotective, radiosensitizing and chemosensitizing properties. Phytochemicals such as curcumin, genistein, resveratrol, diallyl sulfide, S-allyl cysteine, allicin, lycopene, capsaicin, diosgenin, [6]-gingerol, ellagic acid, ursolic acid, silymarin, anethol, catechins, eugenol, isoeugenol, isothiocyanates, indole-3-carbinol, isoflavones, phytosterols, folic acid, $\beta$-carotene and flavonoids are widely investigated for their radiosensitizing and chemosensitizing properties [21]. Table 1 summarizes the major South Asian medicinal plants and their active ingredients.

Table 1. Bioactive compounds from selected South Asian medicinal plants.

\begin{tabular}{ll}
\hline Name of the Plant & Bioactive Compounds \\
\hline Withania somnifera L. & WithaferinA, withanolide \\
Phyllanthus amarus & Nirtetralin, niranthrin, phyllanthin, phyltetralin \\
Aegiceras corniculatum L. & Embilins \\
Annona muricataLinn & Annomuricins, bullatacin \\
Cedrus deodara & (-)-Wikstromal, $(-)$-matairesinoland dibenzylbutyrolactol \\
Nothapodytes foetida Miers & Camptothecin, irinotecan \\
Boswellia serrata Roxb. & Boswellic acid, acetyl- $\beta$-boswellic acid, $\alpha$-pinene \\
Andrographis paniculata & Andrographolide, betulin, betulinic acid \\
Centella asiatica L. & Asiaticoside, hydrocotyline, vallerine, pectic acid, stigmasterol, \\
& thankunosides and ascorbic acid \\
Coscinium fenestratum & Berberine, palmatine, 8-oxoprotoberberine, oxypalmatine, berberrubine \\
Amoora rohituka Roxb. & Amooranin, rohitukine \\
Trichopus zeylanicus & Glycophosphosphingolipids \\
Bruguiera gymnorrhizais L. & Diterpenoids and pimaren \\
Cuscuta reflexa Roxb. & Cuscutin, amarbelin, $\beta$-sterol, stigmasterol, kaempferol, dulcitol, myricetin, \\
& quercetin, coumarin and oleanolic acid \\
Dendrophthoe falcata (L.F.) & Quercetrin, catechin, gallic acid, chebulinic acid, oleonolic acid, \\
& $\beta$-amyrin-O-acetate, leucocynidin, $\beta$-sitosterol and stigmasterol \\
\hline
\end{tabular}


Table 1. Cont.

\begin{tabular}{|c|c|}
\hline Name of the Plant & Bioactive Compounds \\
\hline Dioscorea bulbifera L. & $\begin{array}{l}\text { Kaempferol-3,5-dimethyl ether, caryatin, (L)-catechin, myricetin, } \\
\text { quercetin-3-O galactopyranoside, myricetin-3-O-galactopyranoside, } \\
\text { diosbulbin B }\end{array}$ \\
\hline Embelia ribes Burm. & Quercitol, diethylnitrosamine/Phenobarbital \\
\hline Ficus benghalensis L. & Lupeol, psoralen and $\beta$-sisterol \\
\hline Ficus religiosa $\mathrm{L}$. & Quercetin and qyricetin, stigmasterol and $\beta$-sitosterol \\
\hline Hibiscus tiliaceus L. & Stigmasterol $\beta$-sitosterol, quercetin, kaempferol \\
\hline Jatropha gossypiifolia L. & Falodone and jatrophone \\
\hline Vitex agnus-castus & $\begin{array}{l}\text { Agnucastoside A, agnucastoside B and agnucastoside C, aucubin, agnuside, } \\
\text { mussaenosidic acid }\end{array}$ \\
\hline Mollugo pentaphylla L. & $\begin{array}{l}\text { Apigenin and mollupentin, mmollugogenol A, mollugogenol B, } \\
\text { mollugogenol D, oleanolic acid and } \beta \text {-sitosterol }\end{array}$ \\
\hline Nelumbo nucifera Willd. & $\begin{array}{l}\text { Liensinine, neferine, pronuciferine, isoliensinine, negferine, asimilobine, } \\
\text { nuciferine, remrefidine, isoliensinine, myricetin, quercetin, leucocyanidin, } \\
\text { kaempferol, astragalin }\end{array}$ \\
\hline Nyctanthes arbor-tristis L. & $\begin{array}{l}\text { Phenylpropanoid glycosides, carotenoid glucosides, phenyl-propanoid } \\
\text { glycoside cardiac glycosides, polysaccharides, } \beta \text {-sitosterol, } \beta \text {-amyrin, } \\
\text { hentriacontane benzoic acid, nyctanthic acid, friedelin, lupeol, oleanolic acid, } \\
6 \beta \text {-hydroxylonganin alkaloids, phlobatanins, terpenoids }\end{array}$ \\
\hline Eugenia singampattiana & $\begin{array}{l}\text { 4-Hydroxybenzoic acid, caffeic acid, rutin, ferulic acid, coumaric acid, } \\
\text { epigallocatechin gallate, quercetin, myricetin, and kaempferol }\end{array}$ \\
\hline Solanum nigrum $\mathrm{L}$. & $\begin{array}{l}\text { Gentisic acid, luteolin, apigenin, kaempferol, m-coumaric acid, } \\
\text { anthocyanidin, lunasin }\end{array}$ \\
\hline Strychnos nux-vomica & Brucine, diaboline \\
\hline Zingiber officinale & Gingerenonea, gingeols, shogaols, zingerone \\
\hline Chloroxylon swietenia & Coumarins xanthyletin, xanthoxyletin and 7-demethylsuberosin \\
\hline Podophyllum hexandrum B & Podophyllin, astragalin \\
\hline Linum usitatissimum & Cynogenetic glycosides \\
\hline Glycyrrhiza glabra & Glycyrrhizin \\
\hline Catharanthus roseus & Vinblastine, vincristine, alstonine, ajmalicine and reserpine \\
\hline Camellia sinensis & Epigallocatechin gallate \\
\hline Aloe ferox, Aloe barbadenis & Aloe-emodin, emodin, aloin acemannan \\
\hline Allium sativum & $\begin{array}{l}\text { Alliin, allicin alliin, alliinase, S-allylcysteine, diallyldisulphide, } \\
\text { diallyltrisulphide and methylallyltrisuphide. }\end{array}$ \\
\hline Curcuma longa & Curcumin \\
\hline Capsicum annuum & Capsaicin \\
\hline Piper nigrum & Piperidine, piperine \\
\hline
\end{tabular}

\section{South Asian Medicinal Compounds as Chemosensitizers and Radiosensitizers}

Chemotherapy works by targeting cells within the body that divide rapidly, which is one of the prominent characteristics of cancer cells. Radiation treatment damages the DNA of the cancer cells, leading to cell death. One of the primary causes for therapeutic failure in cancer is resistance to radiation and chemotherapeutic drugs. Cancer cells employ several mechanisms to resist chemotherapy and radiotherapy (Table 2). Some tumors develop resistance to structurally and chemically unrelated anticancer drugs, termed multidrug resistance (MDR). This is one of the most dreadful challenges to cancer chemotherapy [22]. Tumors usually consist of a mixed population of malignant cells, some drug-sensitive, and some drug-resistant. Cancer cells that show resistance to chemotherapy when first exposed to an anticancer drug have intrinsic MDR [23]. Chemotherapy usually destroys drug-sensitive cells, and favors the survival of drug-resistant cells. After an initial treatment with chemotherapy, the tumor begins to grow again and develop resistance to chemotherapeutic agents [24]. Furthermore, drug resistance involves altered drug transport across the plasma membrane, genetic responses, enhanced DNA repair, modification of target molecules and access to target cells, metabolic effects, and various growth factors. Some of the mechanisms used by cancer cells to resist cytotoxic drugs 
are also observed in normal cells. They are part of the defense mechanisms that protect cells from environmental carcinogens.

Table 2. Mechanisms by which tumor cells resist radiation and chemotherapeutic drugs.

\begin{tabular}{ll}
\hline Radioresistance & Chemoresistance \\
\hline Tumor hypoxic condition & Increased drug efflux and decreased drug uptake \\
Increased cellular production of cellular antioxidants & Inactivation of apoptosis \\
Activation of certain proto-oncogenes, and & Increased drug metabolism and drug \\
stromal interactions & compartmentalization \\
Amplification of DNA repair genes & Increase in the repair of DNA damage \\
Cancer stem cells as contributors to radioresistance & Increased or altered the drug targets \\
Survival signals favoured by transcription factors & Survival signals favoured by transcription factors \\
\hline
\end{tabular}

Multidrug resistance in cancer cells mainly develops by the overexpression of ATP-binding cassette $(\mathrm{ABC})$ drug transporters. This is considered to be a major impediment to clinical cancer chemotherapy [25]. This condition occurs when cancer cells spontaneously become insensitive to structurally and functionally unrelated drugs. ABC transporters utilize energy derived from ATP hydrolysis to actively transport anticancer drugs across biological membranes, preventing drugs from reaching their targets within a cancer cell [26]. The $A B C$ transporters belong to a superfamily of proteins that are classified into seven subfamilies (ABCA-ABCG) based on their sequence. However, only three major $A B C$ drug transporters, including P-glycoprotein (P-gp; $A B C B 1)$, multidrug resistance protein 1 (MRP1; ABCC1) and ABCG2 (BCRP; MXR), are believed to seriously affect cancer chemotherapy [27].

Tumor cells acquire changes through many possible mechanisms and have increased resistance to apoptosis. They include inactivation of the p53 tumor-suppressor gene, activating mutations of the gene for PI3K, and activating mutations of the genes for the RAS/RAF pathway. Bcl-2 phosphorylation followed by activation of the NF- $\mathrm{KB}$ transcription factor and its downstream targets can lead to resistance to apoptosis. Tumor cell cytokinetics also can contribute to MDR [28], as well as other mechanisms, such as microsatellite instability and defective DNA repair, whereby tumour cells develop genetic changes.

Inhibiting the function of $\mathrm{ABC}$ drug transporters by inhibitors or modulators is one method to ameliorate drug sensitivity in multidrug-resistant cancer cells. The inhibition of $\mathrm{ABC}$ drug transporters during multidrug-resistant cancer chemotherapy allows elevated drug penetration, distribution and accumulation, and restores drug sensitivity. ABC drug transporter inhibitors, also called MDR modulators, chemosensitizers, or MDR reversal agents, are able to reverse resistance against anticancer drugs [29]. Inhibitors influence $A B C$ transporters by specific interactions with proteins, changing the intracellular ATP level, which is the source of energy, or affecting membrane profiles to increase permeability. Inhibitors can affect other biological targets by nonspecific binding. However, the use of inhibitor drugs at the high concentrations necessary to reach a sufficient inhibitory effect may cause toxicity. Some of the south Asian medicinal compounds commonly used as radiosensitizers and chemosensitizers are listed in Figure 1. 


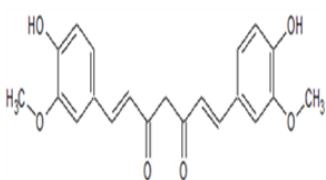

Curcumin<smiles>Oc1ccc(C=Cc2cc(O)cc(O)c2)cc1</smiles>

Resvertrol

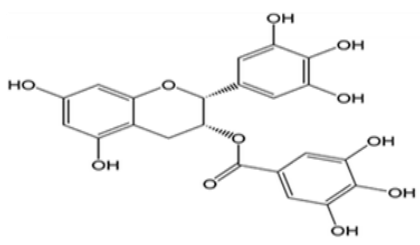

(-)-Epigallocatechin gallate<smiles>CCCCCC(O)CC(=O)CCc1ccc(O)c(OC)c1</smiles>

[6]-Gingerol<smiles></smiles>

Capsaicin<smiles>OCc1c[nH]c2ccccc12</smiles>

Indole-3-carbinol

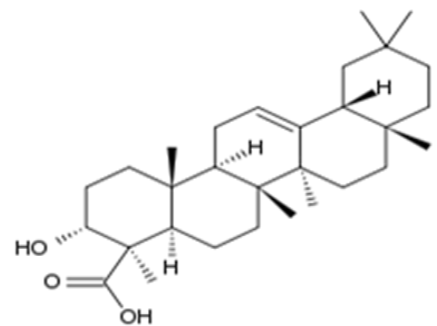

B-Boswellicacid<smiles>O=c1c(O)c(-c2ccc(O)c(O)c2)oc2cc(O)cc(O)c12</smiles>

Quercetin

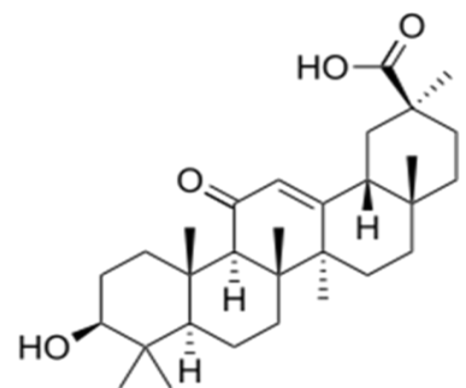

Glycyrrhetinic acid<smiles>Cc1cc(O)c2c(c1)C(=O)c1cc(O)cc(O)c1C2=O</smiles>

Emodin<smiles>O=c1c(O)c(-c2ccc(O)cc2)oc2cc(O)cc(O)c12</smiles>

Kaempferol<smiles>CCCCCCCCCCCCCCCCCCCOC(=O)C=Cc1ccc(O)c(O)c1</smiles>

Figure 1. Chemical structure of selected active compounds derived from South Asian Medicinal Plants.

\section{Phytochemicals as Chemosensitizers}

Currently three generations of chemosensitizers have been developed. Unfortunately, they are all toxic and cause side effects in recipients. Phytochemicals from medicinal plants are considered as fourth generation chemosensitizers to overcome tumor resistance. Examples include withaferin-A (from Withania somnifera), apigenin, kaempferol, anthocyanidin (from Solanum nigrum L); curcumin (from Curcuma longa), and berberine (from Tinospora cordifolia), glycyrrhizin (from Glycyrrhiza glabra) diallyldisulphide, diallyltrisulphide (from Allium sativum), and capsaicin (from Capsicum annuum). These have been shown to accomplish chemosensitizing activities both in vitro and in vivo [30]. 
Curcumin increases intracellular chemotherapeutic drug concentrations of drugs such as vinblastine or vincristine and can inhibit ABC transporters. Curcumin also enhances the cytotoxic effect of 5-FU and sensitizes prostate cancer cells through p53-independent cell-cycle arrest, consequently down-regulating NF-KB activation [31]. Curcumin has been shown to increase the cytotoxic effect of 5-FU and oxaliplatin in colon cancer cells via down-regulation of COX-2 [32,33]. (-)-Epigallocatechin-3-gallate (EGCG) can saturate drug efflux pumps, increasing the accumulation of chemotherapeutic drug within the cell. The substrates in effect sensitize cancer cells to chemotherapeutic agents. Moreover, curcumin is capable of interfering with the function of ABC transporters such as MRP, which needs a balanced supply of reduced glutathione GSH. This kind of inhibition might enhance chemotherapeutic agents by sensitizing cancer cells that overexpress MRP [34]. Targeting c-JUN expression is another clinical strategy to reduce GSH levels to overcome tumor resistance. C-JUN expressions are related with an AP-1-mediated increase in GSH synthetase levels. Curcumin is a strong inhibitor, reducing intracellular GSH at the transcriptional level [35]. Glutathione S-transferase Pi (GST-Pi) expression is linked with resistance to chemotherapeutic agents. Genistein, an isoflavone, is a promising chemosensitizer. Genistein potentiates the efficacy of gemcitabine through the down-regulation of NF-kB and Akt [36,37]; down-regulation of Akt is another mechanism to sensitize cancer cells to the apoptotic effects of TRAIL [38]. Genistein executes its chemosensitizing efficacy by modulating the pathways that cross-talk with TRAIL-induced apoptosis [39]. A number of studies have explored how quercetin enhances the efficiency of anticancer drugs and sensitizes cancer cells to chemotherapy. The efficiency of quercetin to chemosensitize cancer cells to doxorubicin depends on its ability to down-regulate HIF1- $\alpha$, the downregulation of which makes them sensitive to doxorubicin [40]. Emodin is an anthraquinone obtained from Cassia obtusifolia. It is a tyrosine kinase inhibitor that inhibits HER2/neu tyrosine kinase activity, leading to a suppression of tumor growth [41]. Emodin sensitizes chemoresistant cells to paclitaxel-induced apoptosis and increases the intracellular concentration of paclitaxel. It also down-regulates the expression of antiapoptotic molecules and suppresses P-gp expression through ROS generation [42-44].

Resveratrol, a polyphenol, has been shown to sensitize cancer cells to chemotherapeutic drugs by modulating the molecular players of chemoresistance. Resveratrol also increases drug sensitivity through the inhibition of STAT3, NF-kB, c-FLIP, and Bcl-xL [45-47]. The major mechanism behind the chemosensitization of resveratrol to paclitaxel chemotherapy is through the downregulation of Bcl-2 family members and P-gp and inhibition of ERK1/2 and AP-1 pathways, leading to reduced Bcl-xL expression in resistant cells [48]. Resveratrol can be effectively used in combination with several chemotherapeutic agents that show adverse effects such as paclitaxel, vincristine, and daunorubicin in some tumor cells [49-52]. Glycyrrhetinic acid (GA) exhibits cytotoxic activities against HL-60 cells by induction of apoptosis. GA-induced apoptosis is at least partially initiated by interaction of the CD95 and CD178 signaling pathways [53]. Betulinic acid can overcome resistance or cross-resistance effectively. Combination of betulinic acid with irinotecan (IRT) and oxaliplatin (OXT) was effective against SNU-C5/5FU-R cells. Betulinic acid induced cancer cell death by apoptosis through the mitochondrial pathway [54]. The active components of south asian medicinal plants, which have interact with cell surface ABC transporters such as P-gp, ABCG2, and receptor tyrosine kinases including TRIAL-R, FLT3, KIT, VEGFR and EGFR. Some of the medicinal compounds also interact with intracellular tyrosine kinases (BCR-ABL kinase) resulting in chemosensitization (Figure 2). 


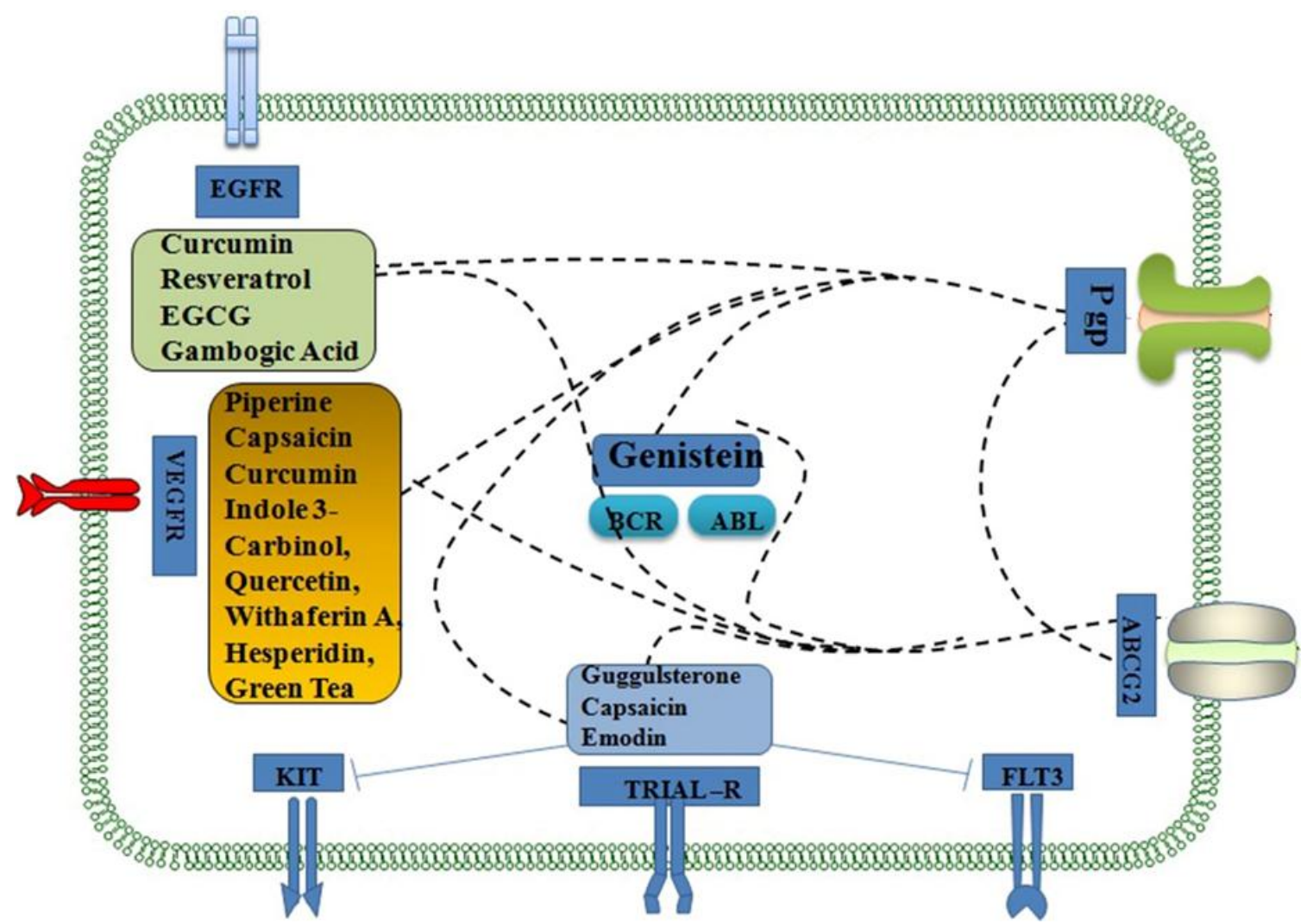

Figure 2. Selected targets of South Asian phytochemicals linked to chemosensitization. The indicated compounds in colored boxes interact with cell surface ABC transporters such as P-gp, ABCG2, and receptor tyrosine kinases including TRIAL-R, FLT3, KIT, VEGFR and EGFR. Some of the medicinal compounds also interact with intracellular tyrosine kinases (BCR-ABL kinase). The dashed lines indicate that the phytochemicals inhibit ABC drug transporters such as P-gp and ABCG2 resulting in chemosensitization. The solid lines depict inhibition of targets such as KIT and FLT3 resulting in chemosensitization.

The ATPase activity of P-gp can be stimulated by number of phytochemicals such as caffeic acid phenyl ester [CAPE], licochalcone A, anacardic acid, celastrol, and xanthohumol. Tumor necrosis factor- $\alpha$ (TNF- $\alpha$ )-mediated NF- $\mathrm{kB}$ activation was inhibited by CAPE, licochalcone A, anacardic acid, and xanthohumol. KB/MDR1 cells were found to be sensitized to vinblastine cytotoxicity by CAPE, licochalcone A, anacardic acid, and xanthohumol. Natural NF- $\mathrm{KB}$ inhibitors reverse multidrug resistance. Some natural compounds, such as CAPE and licochalcone A, have dual inhibitory effects on the anticancer drug efflux transporter P-gp and NF-kB activation [55]. Natural compounds including withanolide, withaferin $\mathrm{A}$ and polyphenol quercetin were shown to inhibit NF- $\mathrm{KB}$ target genes in doxorubicin-sensitive K562 and -resistant K562/Adr cells involved in inflammation, angiogenesis, cell cycle, metastasis, anti-apoptosis and multidrug resistance. Withaferin A can overcome attenuated caspase activation and apoptosis in K562/Adr cells, whereas quercetin-dependent caspase activation decreases intracellular protein levels of Bcl2, Bim and P-Bad [56]. The chemosensitizing potential of certain South Asian medicinal compounds are summarized in Table 3. 
Table 3. Chemosensitizing potential of selected South Asian medicinal compounds.

\begin{tabular}{|c|c|c|c|c|}
\hline Natural Products & Anticancer Drugs & Experimental Models & Mechanism of Action & Ref \\
\hline \multirow{4}{*}{ Morin } & Doxorubicin & MCF-7 MDA435/LCC6 cells & $\begin{array}{l}\text { Inhibit P-gp-mediated drug efflux and potentiate } \\
\text { doxorubicin cytotoxicity in P-gp positive cells. }\end{array}$ & {$[4]$} \\
\hline & Vincristine & K562 and K562/ADM & $\begin{array}{l}\text { Pentaethylmorin remarkably increased the drug uptake } \\
\text { in MDR cells. }\end{array}$ & [57] \\
\hline & Daunorubicin & $\begin{array}{l}\text { Multidrug resistant human breast } \\
\text { cancer cell lines }\end{array}$ & $\begin{array}{l}\text { Increased }[3 \mathrm{H}] \text { daunorubicin accumulation in MDR } \\
\text { breast cell lines. }\end{array}$ & {$[4]$} \\
\hline & Doxorubicin & MCF-7 and MDA435/L & Potentiates doxorubicin cytotoxicity in MDA435/L cells. & {$[4]$} \\
\hline Biochanin A & Doxorubicin & MCF-7 MDA435/LCC6 cells & $\begin{array}{l}\text { Biochanin A can potentiate doxorubicin cytotoxicity in } \\
\text { Pgp positive cells }\end{array}$ & {$[4]$} \\
\hline \multirow{6}{*}{ Quercetin } & Vincristine & K562 and K562/ADM & $\begin{array}{l}\text { Pentamethyl quercetin and pentaallylquercetin } \\
\text { remarkably increase drug uptake }\end{array}$ & [58] \\
\hline & Vincristine & MBEC4 cells and ddY mice & $\begin{array}{l}\text { Increased drug uptake in cells and enhanced } \\
\text { brain-to-plasma concentration ratio in mice }\end{array}$ & [59] \\
\hline & Doxorubicin & Cultured rat hepatocytes & Reduced drug retention with increase in its efflux & [60] \\
\hline & Tamoxifen & Female SD rats & AUC, Ka, Cmax increased & [61] \\
\hline & Paclitaxel & Male SD rats & AUC, Ka, Cmax increased & [62] \\
\hline & $\begin{array}{l}\text { Vinblastine and } \\
\text { paclitaxel }\end{array}$ & MDR KB-V1 cells & Reduced P-gp expression and function. & [63] \\
\hline Phloretin & Doxorubicin & MCF-7 MDA435/LCC6 cells & $\begin{array}{l}\text { Inhibit P-gp-mediated drug efflux; phloretin can } \\
\text { potentiate doxorubicin cytotoxicity in P-gp } \\
\text { positive cells. }\end{array}$ & {$[4]$} \\
\hline Nobiletin & Vincristine & K562/ADM & Increased drug uptake in K562/ADM cells. & [57] \\
\hline Chrysin & Vincristine & MBEC4 cells and ddY mice & $\begin{array}{l}\text { Increased drug uptake in cells and enhanced } \\
\text { brain-to-plasma concentration ratio in mice }\end{array}$ & [59] \\
\hline Kaempferol & Doxorubicin & Cultured rat hepatocytes & $\begin{array}{l}\text { Kaempferol potentiated the toxic effect of } \\
\text { chemotherapeutic agent and decreasing the efflux } \\
\text { of doxorubicin }\end{array}$ & {$[64]$} \\
\hline $\begin{array}{l}\text { (-)-Epigallocatechin } \\
\text { gallate (EGCG) }\end{array}$ & Doxorubicin & P-gp over-expressing KB-C2 cells & Increased drug accumulation & $\begin{array}{l}{[65,} \\
66] \\
\end{array}$ \\
\hline $\begin{array}{l}\text { Green tea } \\
\text { polyphenols }\end{array}$ & Vinblastine & $\begin{array}{l}\text { Multidrug-resistant cell line } \\
\mathrm{CH}(\mathrm{R}) \mathrm{C} 5\end{array}$ & Potentiates the vinblastine cytotoxicity in $\mathrm{CH}(\mathrm{R}) \mathrm{C} 5$ cells. & [67] \\
\hline
\end{tabular}


Table 3. Cont

\begin{tabular}{|c|c|c|c|c|}
\hline Natural Products & Anticancer Drugs & Experimental Models & Mechanism of Action & Ref \\
\hline Genistein & $\begin{array}{l}\text { Rhodamine } 123 \\
\text { and daunorubicin }\end{array}$ & P-gp-expressing cells & Elevation in intracellular drug accumulation & [68] \\
\hline \multirow[t]{2}{*}{ Kaempferol } & $\begin{array}{l}\text { Vinblastine and } \\
\text { paclitaxel }\end{array}$ & MDR KB-V1 cells & Reduced P-gp expression and function & $\begin{array}{l}{[69,} \\
70]\end{array}$ \\
\hline & Tamoxifen & male rats & AUC, Ka, Cmax increased & [71] \\
\hline Heptamethoxyflavone & vincristine & K562/ADM & Increased uptake of $[3 \mathrm{H}]$ vincristine & \\
\hline Phloretin, silymarin & $\begin{array}{l}\text { Daunorubicin\& } \\
\text { doxorubicin }\end{array}$ & $\begin{array}{l}\text { Multidrug resistant human breast } \\
\text { cancer cell lines MCF- } 7 \text { and } \\
\text { MDA435/L }\end{array}$ & $\begin{array}{l}\text { Increased [3 H]Daunomycin accumulation \& } \\
\text { potentiated doxorubicin Cytotoxicity }\end{array}$ & {$[4]$} \\
\hline EGCG & Paclitaxel & $\begin{array}{l}\text { Breast cancer cells (4T1, MCF- } 7 \text {, and } \\
\text { MDA-MB- 231) Female Balb/c mice } \\
\text { (4T1) cells xenograft) and various } \\
\text { carcinoma cells }\end{array}$ & $\begin{array}{l}\text { Induces apoptosis and increased endoplasmic reticulum } \\
\text { chaperone GRP78 expression in tumor tissues. } \\
\text { Decreases PCNA immunostaining }\end{array}$ & $\begin{array}{l}{[72-} \\
74]\end{array}$ \\
\hline \multirow[t]{3}{*}{ Curcumin } & Carboplatin & NSCLC cell line, A549 & $\begin{array}{l}\text { Suppression of NF- } \mathrm{B} \text { B via inhibition of the Akt/IKK } \alpha \\
\text { pathway and enhanced ERK1/2 activity }\end{array}$ & {$[75-$} \\
\hline & Paclitaxel & Cervical cancer cells & $\begin{array}{l}\text { Down-regulation of paclitaxel-induced activation of } \\
\text { NF- } k B, A k t \text {, and Bcl-2 }\end{array}$ & $\begin{array}{l}{[78,} \\
79]\end{array}$ \\
\hline & $\begin{array}{l}\text { Vincristine/ } \\
\text { vinblastine }\end{array}$ & $\begin{array}{l}\text { Multidrug resistant KB cells, } \\
\text { human multiple myeloma cells }\end{array}$ & Down-regulated NF-kB or P-gp & $\begin{array}{l}{[80-} \\
82]\end{array}$ \\
\hline EGCG + Curcumin & Cisplatin & $\begin{array}{l}\text { Ovarian cancer, A2780, A2780cisR } \\
\text { and A2780ZD0473R cells }\end{array}$ & $\begin{array}{l}\text { Lower concentrations and shorter time gap between the } \\
\text { two treatments produces higher cytotoxic effects }\end{array}$ & $\begin{array}{l}{[83,} \\
84]\end{array}$ \\
\hline \multirow[t]{2}{*}{ Resveratrol } & $5-\mathrm{FU}$ & $\begin{array}{l}\text { Chemoresistant } \\
\text { cholangiocarcinoma tumor model } \\
\text { and B16 murine melanoma cells }\end{array}$ & $\begin{array}{l}\text { Down-regulates Cyp } 1 \text { b1 expression and suppresses cell } \\
\text { growth and angiogenesis }\end{array}$ & $\begin{array}{l}{[85,} \\
86]\end{array}$ \\
\hline & Paclitaxel & $\begin{array}{l}\text { nonHodgkin's lymphoma and } \\
\text { multiple myeloma cell } \\
\text { lines, KBv200 }\end{array}$ & $\begin{array}{l}\text { Down-regulation of Bcl-2 family members and } \\
\text { MDR1/P-gp. Down-regulation of Bcl-2 family } \\
\text { members and MDR1/P-gp. }\end{array}$ & [48] \\
\hline
\end{tabular}


Table 3. Cont

\begin{tabular}{|c|c|c|c|c|}
\hline Natural Products & Anticancer Drugs & Experimental Models & Mechanism of Action & Ref. \\
\hline & $\begin{array}{l}\text { Doxorubicin or } \\
\text { vincristine }\end{array}$ & $\begin{array}{l}\text { human uterine cancer cells, } \\
\text { doxorubicin-resistant acute } \\
\text { myeloid leukemia cells }\end{array}$ & Down-regulation of MDR1/P-gp and Bcl-2 & $\begin{array}{l}{[87,} \\
88]\end{array}$ \\
\hline $\begin{array}{l}\text { Caffeic Acid } \\
\text { Phenylethyl Ester }\end{array}$ & $\begin{array}{l}\text { Vincristine and } \\
\text { Doxorubicine }\end{array}$ & PL104 cells & CAPE an enhancement of cell death & [89] \\
\hline Green tea & Doxorubicin & M5076 sarcoma & Increase in accumulation of the antitumor agent & $\begin{array}{l}{[90,} \\
91]\end{array}$ \\
\hline $\begin{array}{l}\text { Withaferin A and } \\
\text { Siamois }\end{array}$ & Doxorubicin & K562 and K562/Adr cells & $\begin{array}{l}\text { Transcriptional inhibition of NF-kB-, AP1- and Nrf2- } \\
\text { and overcome the P-gp-coupled attenuation of } \\
\text { caspase-dependent apoptosis in K562/Adr cells }\end{array}$ & [56] \\
\hline Piperine & Cyclosproine A & $\begin{array}{l}\text { Human colon carcinoma cell line } \\
\text { (Caco-2) }\end{array}$ & $\begin{array}{l}\text { Piperine might affect disposition of drugs that are } \\
\text { substrates for both P-glycoprotein and CYP3A4 }\end{array}$ & [92] \\
\hline Capsaicin & 5-flourouracil & Gastric cancer cell line HGC-27 & $\begin{array}{l}\text { Capsaicin has the potential to treat gastric carcinoma } \\
\text { with 5-FU in vitro }\end{array}$ & [93] \\
\hline Diallyltrisulfide & Doxorubicin & K562/A02 cells & $\begin{array}{l}\text { Increased expression of Caspase- } 3 \text { and down-regulation } \\
\text { of NF- } \mathrm{KB} / \mathrm{p} 65 \text {, increasing intracellular adriamycin } \\
\text { concentration and inducing apoptosis }\end{array}$ & [94] \\
\hline Diallylsulfide & Vinblastine & K562 cells & $\begin{array}{l}\text { Enhanced cytotoxic activity of vinblastine as well as } \\
\text { other Vinca alkaloids }\end{array}$ & $\begin{array}{l}995, \\
96]\end{array}$ \\
\hline Emodin & Paclitaxel & $\begin{array}{l}\text { MDA-MB-361, MDA-MB- } 453 \\
\text { BT- } 483, \text { SKBr-3, and BT- } 474 \text { cells }\end{array}$ & Sensitizes HER-2/neu-overexpressing breast cancer cells & {$[44]$} \\
\hline Glycyrrhetinic acid & Daunorubicin & $\begin{array}{l}\text { Human carcinoma KB-C2 cells and } \\
\text { human MRP1 gene-transfected } \\
\text { KB/MRP cells }\end{array}$ & Dual inhibitory effects on P-glycoprotein and MRP1 & $\begin{array}{l}{[97,} \\
98]\end{array}$ \\
\hline (-)-Hydnocarpin & Vincristine & $\begin{array}{l}\text { Acute lymphoblastic leukemia } \\
\text { cell line }\end{array}$ & $\begin{array}{l}\text { Hydnocarpin potentiating the effect of vincristine in a } \\
\text { multidrug-resistant cell line }\end{array}$ & [99] \\
\hline Hesperidin & Doxorubicin & $\begin{array}{l}\text { MCF-7 cell line, doxorubicin } \\
\text { resistant (MCF-7/Dox) cells }\end{array}$ & $\begin{array}{l}\text { Co-chemotherapy application of doxorubicin and } \\
\text { hesperidin on MCF-7/Dox cells showed synergism } \\
\text { effect through inhibition of Pgp expression. }\end{array}$ & [100] \\
\hline
\end{tabular}




\section{Radioresistance}

When irradiation is unable to reduce tumor volume or cancer recurs after a regression, then a cell is considered to be radioresistant. Chemotherapy, radiotherapy and surgery are the major therapeutic options for treatment of human malignancies. Nearly 50\% of newly diagnosed cancer patients receive radiotherapy (alone or in combination with chemotherapy or surgery) for their treatment [101]. Nevertheless, the curative potential of radiotherapy is limited by intrinsic radioresistance of cancer cells and normal tissue toxicity [102]. The degree of radiosensitivity is recognized by both intrinsic and extrinsic properties. Intrinsic properties include DNA repair, cell cycle status, and survival pathways, while extrinsic properties include cues from the extracellular environment [103]. Radioresistance has an effect on various biological factors such as DNA repair, gene amplification, increases in cellular production of free radical scavengers (eg, glutathione), proto-oncogene activation, and stromal interactions. DNA repair, apoptosis, growth factors, signal transduction, the cell cycle and cell adhesion are associated with genes related to radiosensitivity. The expression of p53 [104], ras [105], raf-1 [106], Bcl-2 [107] and survivin [108] genes are associated with radioresistance. In addition, cancer stem cells have emerged as a contributor to radioresistance through the activation of the DNA damage checkpoint response and an increase in DNA repair capacity [109]. Consequently, there is an increase in interest in enhancing the radiosensitivity of cancer cells for development of effective therapies [110].

\section{Radiosensitization}

A radiosensitizer is a drug that makes tumor cells more sensitive to radiotherapy. Radiosensitization is useful in cancer therapy, as it can enhance the effect of therapeutic radiation. An incredible amount of research and clinical trials have been performed on chemical agents that mimic the radiosensitizing effects of oxygen. Metronidazole, misonidazole, etanidazole and nimorazole are some of the electron-affinity agents used for radiosensitizing effects [111]. Radiosensitizing and radioenhancing agents increase the toxicity of radiation to cancerous tissues, and cause less damage to adjacent normal parenchyma cells. In addition to normal and hypoxia-based radiosensitizers, various other types of sensitizing agents have also been tried on malignant brain tumors. Preclinical research often shows significant promise, but unfortunately, the clinical efficacy of such agents has generally been modest at best [112]. For example, grade III gliomas when treated with conventional radiotherapy and estramustine, an estradiol-based antimicrotubule effector showed a positive improved response. [113].

\section{Radiosensitizing Properties of South Asian Medicinal Compounds}

Radiosensitization has generally been limited to the combination of radiation therapy with traditional cytotoxic agents such as hydroxyurea, 5-fluorouracil and cisplatin. Thus, radiotherapy has been combined with molecular targeted agents, which blocks specific pro-survival signaling pathways [114]. Two brain tumor radiosensitizers have received a great degree of interest of late: motexafin gadolinium (MGd) and efaproxiral [115]. Most patients with cancer receive radiotherapy at some point during the course of their treatment. The efficacy of treatment depends on the total dose of radiation, the fractionation scheme, the degree of oxygenation of tumors and the normal tissue response to radiation. The heterogeneity of tumors and their response to treatment, in early experimental and theoretical studies in radiobiology, were identified. DNA strand-break repair, repopulation of cancer cells between radiation fractions, reoxygenation of tumors after a radiation fraction and redistribution of cells into a radioresistant phase of the cell cycle were considered to be the four classical mechanisms of radioresistance [116]. Understanding the molecular basis of these processes can permit selective targeting of the molecules and pathways that regulate cellular radioresponse. Radiation activates pro-survival signaling pathways, to target normal tissue responses such as angiogenesis and also exploit radiation-induced gene expression for other therapeutic modalities [117].

Many natural or naturally derived compounds have shown cytotoxic effects in cancer cells. Compounds such as vinblastine, vincristine, taxol, and camptothecin have been approved for clinical practice [118]. These anticancer drugs act through several mechanisms to kill tumors: Microtubule 
polymerization, mitotic inhibition [119], and inhibition of DNA topoisomerase I enzyme [120]. Genotoxicity is the main tumoricidal effect of anticancer agents. The effectiveness of radiation therapy on cancer cells is enhanced when the anticancer products are co-administered with IR during radiotherapy. Treating cells with radiosensitizers before irradiation probably sensitizes the cell cycle phase to radiotherapy [121,122]. The presence of natural compounds during irradiation enhances their effects by increasing the toxic reactions of free radicals and inhibiting the repair of the radiation induced lethal and sub-lethal damage by misregulation of signal pathways [123]. The active components of south asian medicinal plants, which have rediosensitizing properties, and their molecular targets are described in Figure 3.

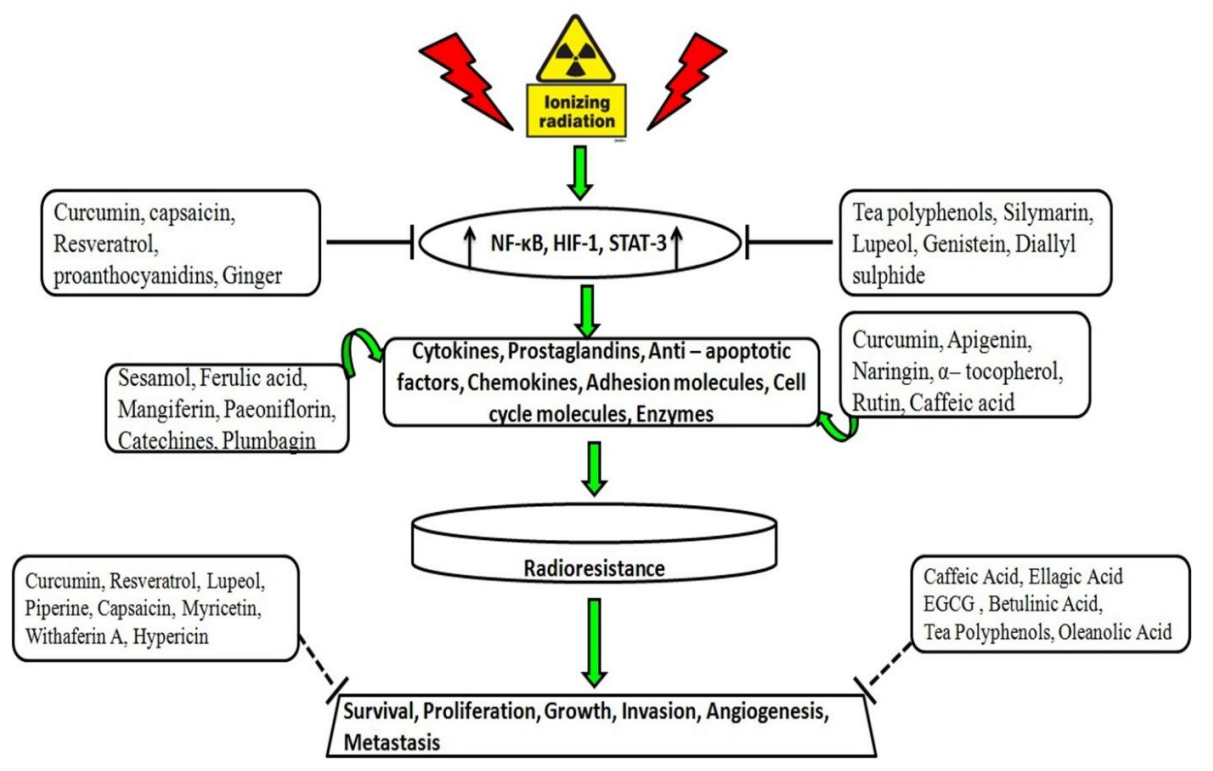

Figure 3. Selected targets of South Asian phytochemicals linked to radiosensitization. Exposure to ionizing radiation leads to activation of several transcription factors, expression of numerous cytokines, adhesion molecules, prostaglandins and enzymes that promote radioresistance. The upward black arrows depict up-regulation of indicated transcription factors. Solid lines indicate South Asian medicinal compounds inhibiting transcription potential of pro-inflammatory transcription factors. The curved green arrows indicate downregulation of expression of proinflammatory cytokines and enzymes involved in radioresistance by South Asian medicinal compounds. Dotted lines indicate South Asian medicinal compounds involved in the inhibition of prosurvival, cell proliferation, growth, invasion, angiogenesis and metastasis through various mechanisms.

\section{Radioprotective Effects of Natural Compounds}

Radioprotectors are agents that protect normal cells during radiotherapy. Radioprotective agents protect macromolecules, cells, and tissues from radiation-induced toxicity. These agents are administered before exposure to radiation. Several mechanisms are proposed for radioprotective agents: Direct scavenging of ROS, hydrogen donation to reactive free radicals, inducing/altering the levels of endogenous enzymes for detoxifying ROS, anti-inflammatory action, immune-stimulant activity, increasing DNA stability, reducing the production of ROS by inducing hypoxia, and enhancing DNA damage repair pathways [124-126]. Pretreatment with natural compounds with antioxidant activity protects biological systems against oxidative stress. Because natural products have fewer side effects, they are increasingly being used as radioprotective agents. Polyphenols from herbal plants have protective effects against genotoxicity induced by $\gamma$-irradiation. Natural compounds reduce DNA damage and genomic instability induced by ROS in vitro and in vivo. Flavonoids have excellent antioxidant activity through various mechanisms, and flavonoids with more antioxidant activity have higher radioprotective effects [127]. Table 4 summarizes some of these natural products that act as radioprotectors in normal cells and radiosensitizers in cancer cells through different mechanisms. 
Table 4. South Asian medicinal compounds protect normal cells from radiation effects and sensitize cancer cells to radiation effects. South Asian medicinal compounds at the concentration studied protects the normal human cells and experimental animals against indicated radiation dose and sensitizes radiation effects in the cancer cells through different mechanism.

\begin{tabular}{|c|c|c|c|c|}
\hline $\begin{array}{l}\text { Name of the } \\
\text { Hytochemicals }\end{array}$ & $\begin{array}{l}\text { Concentration } \\
\text { Studied }\end{array}$ & $\begin{array}{l}\text { Radiation } \\
\text { Dose }\end{array}$ & Radioprotective/Radiosensitizing Effect & References \\
\hline \multicolumn{5}{|c|}{ (i) Radioprotective phytochemicals } \\
\hline Curcumin & $50 \mu \mathrm{g} / \mathrm{mL}$ & $1.5 \mathrm{~Gy}$ & $\begin{array}{l}\text { Curcumin-encapsulated bioglass-chitosan might have promising potential } \\
\text { applications for wound healing resulting from gamma radiation. }\end{array}$ & [127] \\
\hline \multirow[t]{2}{*}{ Sesamol } & $10 \mu \mathrm{g} / \mathrm{mL}$ & 4 Gy & $\begin{array}{l}\text { (i) Renders protection on } \gamma \text {-radiation induced DNA damage, and } \\
\text { antioxidants depletion in cultured human lymphocytes. }\end{array}$ & \multirow[t]{2}{*}[128,129]{} \\
\hline & $100 \mathrm{mg} / \mathrm{kg}$ & $7.5 \mathrm{~Gy}$ & $\begin{array}{l}\text { (ii) Acts as a single prophylactic dose protects hematopoietic and GI } \\
\text { systems against } \gamma \text {-radiation-induced injury in mice. }\end{array}$ & \\
\hline \multirow[t]{2}{*}{ Ferulic acid } & $10 \mu \mathrm{g} / \mathrm{mL}$ & 4 Gy & $\begin{array}{l}\text { Prevents } \gamma \text {-radiation-induced micronuclei and dicentric aberration in } \\
\text { human lymphocytes. }\end{array}$ & \multirow[t]{2}{*}[130,131]{} \\
\hline & $50 \mathrm{mg} / \mathrm{kg}$ & 4 Gy & $\begin{array}{l}\text { Enhances the survival of mice possibly by decreasing DNA damage as } \\
\text { examined by } \gamma \mathrm{H} 2 \mathrm{AX} \text { foci, micronuclei formation, and comet assay. }\end{array}$ & \\
\hline Apigenin & $10 \mu \mathrm{g} / \mathrm{mL}$ & 3 Gy & $\begin{array}{l}\text { Significantly reduced }(p<0.01) \text { the frequency of mitomycin } \\
\text { C-induced micronuclei. }\end{array}$ & [132] \\
\hline Mangiferin & $5-25 \mu \mathrm{g} / \mathrm{mL}$ & 5 Gy & $\begin{array}{l}\text { Protects against gamma radiation-induced DNA damage and acts as an } \\
\text { antioxidant or pro-oxidant product }\end{array}$ & [133] \\
\hline Naringin & 50 and $100 \mu \mathrm{M}$ & $6 \mathrm{~Gy}$ & Prevents radiation-induced multiple cellular anomalies. & [134] \\
\hline \multirow[t]{2}{*}{ Paeoniflorin } & $200 \mu \mathrm{g} / \mathrm{mL}$ & 4 Gy & $\begin{array}{l}\text { Offers protection against radiation-induced cell damage through } \\
\text { modulation of reactive oxygen species and the mitogen-activated protein } \\
\text { kinases in thymocytes. }\end{array}$ & {$[135]$} \\
\hline & $50-200 \mu \mathrm{g} / \mathrm{mL}$ & 10 Gy & $\begin{array}{l}\text { Protected EA.hy } 926 \text { cells against radiation-induced injury through the } \\
\text { Nrf2/HO-1 pathway. }\end{array}$ & {$[136]$} \\
\hline Luteolin & $10 \mu \mathrm{mol} / \mathrm{kg}$ b.wt. & 6 Gy & Radioprotective effects through antioxidative property in mice. & [137] \\
\hline $\begin{array}{l}\text { Lignans from Myristica } \\
\text { fragrans }\end{array}$ & $500 \mu \mathrm{g} / \mathrm{mL}$ & $4.26 \mathrm{~Gy}$ & Radioprotection through immunomodulation in mammalian splenocytes. & {$[138]$} \\
\hline Hesperidin & $50-100 \mathrm{mg} / \mathrm{kg}$ b.wt. & 5 Gy & $\begin{array}{l}\text { Protects against } \gamma \text {-radiation-induced cellular damage and oxidative stress } \\
\text { in rats. }\end{array}$ & [139] \\
\hline$\alpha$-tocopherol & $360 \mathrm{mg} / \mathrm{kg}$ b.wt. & $15 \mathrm{~Gy}$ & Radioprotective effect of Vitamin E in Parotid Glands in rats. & [140] \\
\hline Catechines & $100 \mu \mathrm{M}$ & 3 Gy & $\begin{array}{l}\text { Protects pBR322 DNA under acellular conditions and normal splenocytes } \\
\text { under cellular conditions, against } \gamma \text {-radiation-induced damage. }\end{array}$ & {$[141]$} \\
\hline Orientin & $17.5 \mu \mathrm{M}$ & 4 Gy & Promotes stem cell survival, exogenous spleen colony formation (CFU-S). & [142] \\
\hline Silymarin & $50 \mathrm{mg} / \mathrm{kg}$ & 3 Gy & Protects experimental animals from radiation-induced hepatotoxicity. & [143] \\
\hline
\end{tabular}


Table 4. Cont.

\begin{tabular}{|c|c|c|c|c|}
\hline $\begin{array}{l}\text { Name of the } \\
\text { Hytochemicals }\end{array}$ & $\begin{array}{l}\text { Concentration } \\
\text { Studied }\end{array}$ & $\begin{array}{l}\text { Radiation } \\
\text { Dose }\end{array}$ & Radioprotective/Radiosensitizing Effect & References \\
\hline Zingerone & $10 \mu \mathrm{g} / \mathrm{mL}$ & 2 Gy & $\begin{array}{l}\text { Prevents radiation-induced genetic damage and apoptosis in human } \\
\text { lymphocytes. }\end{array}$ & [144] \\
\hline Rutin & 10 mg/kg b.wt. & 3 Gy & $\begin{array}{l}\text { Mitigates radiation-induced mortality and cytogenetic damage, which } \\
\text { attributes to scavenging of radiation-induced free radicals. }\end{array}$ & {$[145]$} \\
\hline Lycopene & $5 \mathrm{mg} / \mathrm{kg}$ b.wt. & 6 Gy & $\begin{array}{l}\text { Protects the small intestine against radiation-induced damage. } \\
\text { Offers protection against } \gamma \text {-radiation-induced DNA damage to plasmid }\end{array}$ & [146] \\
\hline Glycyrrhizic acid & $4 \mathrm{mM}$ & $1.25 \mathrm{~Gy}$ & $\begin{array}{l}\text { pBR322 in vitro, human peripheral blood leukocytes and bone marrow } \\
\text { cells in vivo. }\end{array}$ & [147] \\
\hline Naringin & $7.5 \mathrm{mg} / \mathrm{kg}$ b.wt. & $1-5 \mathrm{~Gy}$ & $\begin{array}{l}\text { Protects mouse bone marrow cells against radiation-induced chromosomal } \\
\text { aberrations and lipid peroxidation. }\end{array}$ & [148] \\
\hline Quercetin & $2-50 \mu \mathrm{M}$ & $30 \mathrm{~Gy}$ & Protects against radiation- and storage-induced oxidative damage to RBCs. & [149] \\
\hline Morin & $25 \mu \mathrm{M}$ & $10 \mathrm{~Gy}$ & $\begin{array}{l}\text { Protects against oxidative stress induced by radiation via reduction of ROS } \\
\text { and attenuation of the SEK1-JNK-AP-1 pathway. }\end{array}$ & [150] \\
\hline Dehydrozingerone & $100 \mathrm{mg} / \mathrm{kg}$ b.wt. & $10 \mathrm{~Gy}$ & $\begin{array}{l}\text { Exhibits radioprotective activity in whole body gamma irradiated Swiss } \\
\text { albino mice through free radical scavenging. The DMF value was found to } \\
\text { be } 1.09 \text {. }\end{array}$ & [151] \\
\hline Famotidine & $200 \mu \mathrm{g} / \mathrm{mL}$ & 4-12 Gy & $\begin{array}{l}\text { Suppresses radiation-induced apoptosis with various doses of } \\
\text { gamma-irradiation via radical scavenging and intracellular } \\
\text { antioxidation mechanism. }\end{array}$ & [152] \\
\hline Pilocarpine & 4 mg/kg b.wt. & $15 \mathrm{~Gy}$ & $\begin{array}{l}\text { Amelioration of long term radiation-induced hyposalivation using } \\
\text { prophylactic pilocarpine treatment }\end{array}$ & [153] \\
\hline Podophyllotoxin & $10 \mathrm{nM}$ & $10 \mathrm{~Gy}$ & $\begin{array}{l}\text { Derivatives are used in combination with IR therapy and suggest that the } \\
\text { EGFR-p38/ERK-STAT3/CREB-1-EMT pathway might be a useful target } \\
\text { for suppressing metastasis. }\end{array}$ & [154] \\
\hline \multicolumn{5}{|c|}{ (ii) Radiosensitizing phytochemicals } \\
\hline Hypericin & $5 \mu \mathrm{M}$ & $8 \mathrm{~Gy}$ & Enhancement of radiosensitivity in human malignant glioma cells. & [155] \\
\hline Epigallocatechin-galate & $25 \mathrm{mg} / \mathrm{kg}$ b.wt. & $22 \mathrm{~Gy}$ & Inhibits irradiation-induced pulmonary fibrosis. & {$[156]$} \\
\hline Resveratrol & $1 \mathrm{mg} / \mathrm{mL}$ & 70 kGy & $\begin{array}{l}\text { Reduces toxicity and plays a potent role in the treatment of } \\
\text { inflammatory disease. }\end{array}$ & [157] \\
\hline Curcumin & $100 \mu \mathrm{M}$ & $10 \mathrm{~Gy}$ & Acts as radiosensitizer through prooxidant mechanisms in cancer cells. & {$[158]$} \\
\hline
\end{tabular}


Table 4. Cont.

\begin{tabular}{|c|c|c|c|c|}
\hline $\begin{array}{l}\text { Name of the } \\
\text { Hytochemicals }\end{array}$ & $\begin{array}{l}\text { Concentration } \\
\text { Studied }\end{array}$ & $\begin{array}{l}\text { Radiation } \\
\text { Dose }\end{array}$ & Radioprotective/Radiosensitizing Effect & References \\
\hline Gossypol & $2 \mu \mathrm{M}$ & $6 \mathrm{~Gy}$ & $\begin{array}{l}\text { Radiosensitization of tumour cell lines by depressig double-strand break } \\
\text { repair mechanism. }\end{array}$ & [159] \\
\hline Betulinic acid & $20 \mu \mathrm{M}$ & 2 Gy & $\begin{array}{l}\text { Induces cytotoxicity and radiosensitivity in glioma cells under } \\
\text { hypoxic conditions. }\end{array}$ & {$[160]$} \\
\hline Plumbagin & $750 \mathrm{nM}$ & 2 Gy & $\begin{array}{l}\text { Radiosensitizing effects in cervical cancer cells through modulation of } \\
\text { apoptotic pathway. }\end{array}$ & [161] \\
\hline Withaferin A & $4 \mu \mathrm{M}$ & $10 \mathrm{~Gy}$ & $\begin{array}{l}\text { Enhances radiation-induced apoptosis in Caki cells through induction of } \\
\text { reactive oxygen species, Bcl-2 downregulation and Akt inhibition. }\end{array}$ & {$[162]$} \\
\hline Ellagic acid & $100 \mu \mathrm{mol} / \mathrm{L}$ & $6 \mathrm{~Gy}$ & $\begin{array}{l}\text { Enhances radiation-induced oxidative stress and subsequent cytotoxicity } \\
\text { in tumor cells. }\end{array}$ & [163] \\
\hline Caffeic acid & $10 \mu \mathrm{mol} / \mathrm{kgb} . w \mathrm{t}$. & 7 Gy & $\begin{array}{l}\text { Exhibits curable effects on gamma irradiation-induced cardiac-oxidative } \\
\text { impairment in rats. }\end{array}$ & [164] \\
\hline Genistein & $20 \mu \mathrm{M}$ & 5 Gy & $\begin{array}{l}\text { Acts as a prooxidant in HL- } 60 \text { cells, increases ionizing radiation-induced } \\
\text { cell cycle arrest and sensitivity to apoptotic cell death in human } \\
\text { promyeloid leukemia HL-60 cells. }\end{array}$ & [165] \\
\hline Myricetin & $25 \mu \mathrm{M}$ & 2 Gy & Enhances radiosensitivity of lung cancer A549 and H1299 cells. & {$[114]$} \\
\hline Biochanin A & $1-100 \mu \mathrm{M}$ & 2 Gy & Enhances radiotoxicity in colon tumor cells. & [166] \\
\hline Capsaicin & $1-10 \mu \mathrm{M}$ & $1-8 \mathrm{~Gy}$ & Increases radiation effects in prostate cancer. & [167] \\
\hline Piperine & $40 \mu \mathrm{M}$ & 15 Gy & Enhances radiosensitivity of tumor cells through oxidative mechanism. & {$[168]$} \\
\hline Lupeol & $30 \mu \mathrm{mol} / \mathrm{L}$ & 4 Gy & $\begin{array}{l}\text { Enhances radiosensitivity of human hepatocellular carcinoma cell line } \\
\text { SMMC-7721 in vitro and in vivo. }\end{array}$ & [169] \\
\hline Oleanolic acid & $35 \mu \mathrm{g} / \mathrm{mL}$ & $250 \mathrm{~Gy} / \mathrm{min}$ & $\begin{array}{l}\text { Radiosensitizes tumor cells through the inhibition of GSH } \\
\text { synthesis in vitro. }\end{array}$ & {$[170]$} \\
\hline
\end{tabular}




\section{Conclusions}

Cancer is a multifactorial disease that requires multichannel therapy, including radiotherapy and chemotherapy. Cancer cells acquire resistance to radiotherapy and chemotherapy through different mechanisms. Number of synthetic and semisynthetic radiosensitizers and chemosensitizers were investigated; unfortunately these compounds exhibit adverse reactions in non-target organs. Naturally occurring medicinal compounds are considered to be non-toxic fourth generation chemosensitizers and a majority of these compounds also exhibit radiosensitizing properties. This present review reveals the role and importance of South Asian medicinal compounds as radiosensitizers and chemosensitizers. South Asian medicinal compounds exhibit radiosensitizing and chemsensitizing property through modulating/inhibiting different molecular targets. Thus, South Asian medicinal compounds may be considered as an adjuvant to radio- and chemotherapy for cancer patients.

Acknowledgments: We thank George Leiman for editing the manuscript. This work was supported by the Intramural Research Program of the National Institutes of Health, National Cancer Institute, Center for Cancer Research, and by the Department of Science and Technology, Government of India (DST Grant no. SR/SO/BB-0034).

Author Contributions: Suresh V. Ambudkar and N. Rajendra Prasad conceived, designed and wrote the final version of the review article; Mohana Shanmugam and Ganesan Muthusamy wrote the draft of radioresistance and chemoresistance sections, respectively.

Conflicts of Interest: The authors declare no conflict of interest.

\section{References}

1. Jain, J.B.; Kumane, S.C.; Bhattacharya, S. Medicinal flora of Madhya Pradesh and Chhatisgarh-A review. Indian J. Tradit. Know. 2006, 5, 237-242.

2. Garg, A.; Darokar, M.P.; Sundaresan, V.; Faridi, U.; Luqman, S.R.; Khanuja, S.P.S. Anticancer activity of some medicinal plants from high altitude evergreen elements of Indian Western Ghats. J. Res. Educ. Indian Med. 2007, 13, 1-6.

3. Molnar, J.; Engi, H.; Hohmann, J.; Molnar, P.; Deli, J.; Wesolowska, O.; Michalak, K.; Wang, Q. Reversal of multidrug resitance by natural substances from plants. Curr. Top. Med. Chem. 2010, 10, 1757-1768. [PubMed]

4. Zhang, S.; Morris, M.E. Effects of the flavonoids biochanin A, morin, phloretin, and silymarin on P-glycoprotein-mediated transport. J. Pharm. Exp. Ther. 2003, 304, 1258-1267. [CrossRef] [PubMed]

5. Aggarwal, B.B.; Ichikawa, H.; Garodia, P.; Weerasinghe, P.; Bhatt, I.D.; Pandey, M.K.; Shishodia, S.; Nair, M.G. From traditional Ayurvedic medicine to modern medicine: Identification of therapeutic targets for suppression of inflammation and cancer. Expert. Opin. Ther. Targets 2006, 10, 87-118. [CrossRef] [PubMed]

6. Dhar, M.L.; Dhar, M.M.; Dhawan, B.N.; Mehrotra, B.N.; Ray, C. Screening of Indian plants for biological activity: I. Indian. J. Exp. Biol. 1968, 6, 232-247. [PubMed]

7. Singh, S.S.; Pandey, S.C.; Srivastava, S.; Gupta, V.S.; Patro, B.; Ghosh, A.C. Chemistry and medicinal properties of Tinospora cordifolia (Guduchi). Indian J. Pharmacol. 2003, 35, 83-91.

8. Bharti, A.C.; Donato, N.; Aggarwal, B.B. Curcumin (diferuloylmethane) inhibits constitutive and IL-6-inducible STAT3 phosphorylation in human multiple myeloma cells. J. Immunol. 2003, 171, 3863-3871. [CrossRef] [PubMed]

9. Anto, R.J.; Mukhopadhyay, A.; Denning, K.; Aggarwal, B.B. Curcumin (diferuloylmethane) induces apoptosis through activation of caspase-8, BID cleavage and cytochrome $\mathrm{c}$ release: Its suppression by ectopic expression of Bcl-2 and Bcl-xl. Carcinogenesis 2002, 23, 143-150. [CrossRef] [PubMed]

10. Mukhopadhyay, A.; Bueso-Ramos, C.; Chatterjee, D.; Pantazis, P.; Aggarwal, B.B. Curcumin downregulates cell survival mechanisms in human prostate cancer cell lines. Oncogene 2001, 20, 7597-7609. [CrossRef] [PubMed]

11. Bible, K.C.; Kaufmann, S.H. Flavopiridol: A cytotoxic flavone that induces cell death in noncycling A549 human lung carcinoma cells. Cancer Res. 1996, 56, 4856-4861. [PubMed]

12. Manna, S.K.; Mukhopadhyay, A.; Aggarwal, B.B. Resveratrol suppresses TNF-induced activation of nuclear transcription factors NF-kappa B, activator protein-1, and apoptosis: Potential role of reactive oxygen intermediates and lipid peroxidation. J. Immunol. 2000, 164, 6509-6519. [CrossRef] [PubMed] 
13. Kim, D.M.; Koo, S.Y.; Jeon, K.; Kim, M.H.; Lee, J.; Hong, C.Y.; Jeong, S. Rapid induction of apoptosis by combination of flavopiridol and tumor necrosis factor (TNF)-alpha or TNF-related apoptosis-inducing ligand in human cancer cell lines. Cancer Res. 2003, 63, 621-626. [PubMed]

14. Murakami, A.; Takahashi, D.; Kinoshita, T.; Koshimizu, K.; Kim, H.W.; Yoshihiro, A.; Nakamura, Y.; Jiwajinda, S.; Terao, J.; Ohigashi, H. Zerumbone, a Southeast Asian ginger sesquiterpene, markedly suppresses free radical generation, proinflammatory protein production, and cancer cell proliferation accompanied by apoptosis: The alpha,beta-unsaturated carbonyl group is a prerequisite. Carcinogenesis 2002, 23, 795-802. [CrossRef] [PubMed]

15. Kirtikar, K.R.; Basu, B.D. Indian Medicinal Plant; Lalit Mohan Publication: Calcutta, India, 1935.

16. Takada, Y.; Andreeff, M.; Aggarwal, B.B. Indole-3-carbinol suppresses NF-kappaB and Ikappa- $\beta$ alpha kinase activation, causing inhibition of expression of NF-kappaB-regulated antiapoptotic and metastatic gene products and enhancement of apoptosis in myeloid and leukemia cells. Blood 2005, 106, 641-649. [CrossRef] [PubMed]

17. Behera, B.; Devi, K.S.; Mishra, D.; Maiti, S.; Maiti, T.K. Biochemical analysis and antitumour effect of Abrus precatorius agglutinin derived peptides in Ehrlich's ascites and B16 melanoma mice tumour model. Environ. Toxicol. Phar. 2014, 38, 288-296. [CrossRef] [PubMed]

18. Dhiman, A.; Hiremath, S.K.; Pathak, M.; Mishra, D. A review article on anticancerous drugs in ayurveda and screened anticancer activity of medicinal plants. Int. J. Ayu. Alt. Med. 2014, 2, 54-60.

19. Rai, M.; Jogee, P.S.; Agarkar, G.; Santos, C.A. Anticancer activities of Withania somnifera: Current research, formulations, and future perspectives. Pharm. Biol. 2015, 7, 1-9.

20. Nasri, H.; Baradaran, A.; Shirzad, H.; Rafieian-Kopaei, M. New concepts in nutraceuticals as alternative for pharmaceuticals. Int. J. Prev. Med. 2014, 5, 1487-1499. [PubMed]

21. Di Domenico, F.; Foppoli, C.; Coccia, R.; Perluigi, M. Antioxidants in cervical cancer: Chemopreventive and chemotherapeutic effects of polyphenols. Biochim. Biophys. Acta 2012, 1822, 737-747. [CrossRef] [PubMed]

22. Baguley, B.C. Multidrug resistance in cancer. Methods Mol. Biol. 2010, 596, 1-14. [PubMed]

23. Cort, A.; Ozben, T. Natural product modulators to overcome multidrug resistance in cancer. Nutr. Cancer 2015, 67, 411-423. [CrossRef] [PubMed]

24. Chorawala, M.R.; Oza, P.M.; Shah, G.B. Mechanisms of anticancer drugs resistance: An overview. Int. J. Pharm. Sci. Drug Res. 2012, 4, 1-9.

25. Dean, M.; Hamon, Y.; Chimini, G. The human ATP-binding cassette (ABC) transporter super family. J. Lipid Res. 2001, 42, 1007-1017. [PubMed]

26. Coley, H.M. Overcoming multidrug resistance in cancer: Clinical studies of p-glycoprotein inhibitors. Methods Mol. Biol. 2010, 596, 341-358. [PubMed]

27. Gottesman, M.M.; Ambudkar, S.V.; Xia, D. Structure of a multidrug transporter. Nat. Biotechnol. 2009, 27, 546-547. [CrossRef] [PubMed]

28. Krishna, R.; Mayer, L.D. Multidrug resistance (MDR) in cancer: Mechanisms, reversal using modulators of MDR and the role of MDR modulators in influencing the pharmacokinetics of anticancer drugs. Eur. J. Pharm. Sci. 2000, 11, 265-283. [CrossRef]

29. Kitagawa, S. Inhibitory Effects of Polyphenols on P-Glycoprotein-Mediated Transport. Biol. Pharm. Bull. 2006, 29, 1-6. [CrossRef] [PubMed]

30. Chavan, S.S.; Damale, M.G.; Shamkuwar, P.B.; Pawar, D.P. Traditional Medicinal Plants for anticancer activity. Int. J. Curr. Pharm. Res. 2013, 5, 50-54.

31. Shishodia, S.; Potdar, P.; Gairola, C.G.; Aggarwal, B.B. Curcumin (diferuloylmethane) downregulates cigarette smoke-induced NFkappaB activation through inhibition of IkappaBalpha kinase in human lung epithelial cells: Correlation with suppression of COX-2, MMP-9 and cyclin D1. Carcinogenesis 2003, 24, 1269-1279. [CrossRef] [PubMed]

32. Bharti, A.; Takada, Y.; Aggarwal, B. Curcumin (diferuloylmethane) inhibits receptor activator of NF-kappa B ligand-induced NF-kappa B activation in osteoclast precursors and suppresses osteoclastogenesis. J. Immunol. 2004, 172, 5940-5947. [CrossRef] [PubMed]

33. Bharti, A.C.; Shishodia, S.; Reuben, J.M.; Weber, D.; Alexanian, R.; Raj-Vadhan, S.; Estrov, Z.; Talpaz, M.; Aggarwal, B.B. Nuclear factor-kappaB and STAT3 are constitutively active in CD138+ cells derived from multiple myeloma patients, and suppression of these transcription factors leads to apoptosis. Blood 2004, 103, 3175-3184. [CrossRef] [PubMed] 
34. Iersel, M.L.; Ploemen, J.P.; Struik, I.; van Amersfoort, C.; Keyzer, A.E.; Schefferlie, J.G.; van Bladeren, P.J. Inhibition of glutathione S-transferase activity in human melanoma cells by alpha,beta-unsaturated carbonyl derivatives. Effects of acrolein, cinnamaldehyde, citral, crotonaldehyde, curcumin, ethacrynic acid, and trans-2-hexenal. Chem. Biol. Interact. 1996, 102, 117-132. [CrossRef]

35. Duvoix, A.; Morceau, F.; Delhalle, S.; Schmitz, M.; Schnekenburger, M.; Galteau, M.M.; Dicato, M.; Diederich, M. Induction of apoptosis by curcumin: Mediation by glutathione S-transferase P1-1 inhibition. Biochem. Pharmacol. 2003, 66, 1475-1483. [CrossRef]

36. Liang, C.; Li, H.; Shen, C.; Lai, J.; Shi, Z.; Liu, B.; Tao, H.M. Genistein potentiates the anti-cancer effects of gemcitabine in human osteosarcoma via the downregulation of Akt and nuclear factor-kappaB pathway. Anticancer Agents Med. Chem. 2012, 12, 554-563. [CrossRef] [PubMed]

37. Zhang, B.; Shi, Z.L.; Liu, B.; Yan, X.B.; Feng, J.; Tao, H.M. Enhanced anticancer effect of gemcitabine by genistein in osteosarcoma: The role of Akt and nuclear factor-kappaB. Anticancer Drugs 2010, 21, 288-296. [CrossRef] [PubMed]

38. Park, S.Y.; Seol, D.W. Regulation of Akt by EGF-R inhibitors, a possible mechanism of EGF-R inhibitor-enhanced TRAIL-induced apoptosis. Biochem. Biophys. Res. Commun. 2002, 295, 515-518. [CrossRef]

39. Jian, L.; Xie, L.P.; Lee, A.H.; Binns, C.W. Protective effect of green tea against prostate cancer: A case-control study in southeast China. Int. J. Cancer 2004, 108, 130-135. [CrossRef] [PubMed]

40. Du, G.; Lin, H.; Wang, M.; Zhang, S.; Wu, X.; Lu, L.; Ji, L.; Yu, L. Quercetin greatly improved therapeutic index of doxorubicin against $4 \mathrm{~T} 1$ breast cancer by its opposing effects on HIF-1alpha in tumor and normal cells. Cancer Chemother. Pharmacol. 2010, 65, 277-287. [CrossRef] [PubMed]

41. Zhang, L.; Hung, M.C. Sensitization of HER-2/neuoverexpressing non-small cell lung cancer cells to chemotherapeutic drugs by tyrosine kinase inhibitor emodin. Oncogene 1996, 12, 571-576. [PubMed]

42. Li, J.; Liu, P.; Mao, H.; Wanga, A.; Zhang, X. Emodin sensitizes paclitaxel-resistant human ovarian cancer cells to paclitaxel-induced apoptosis in vitro. Oncol. Rep. 2009, 21, 1605-1610. [CrossRef] [PubMed]

43. Huang, X.Z.; Wang, J.; Huang, C.; Chen, Y.Y.; Shi, G.Y.; Hu, Q.S.; Yi, J. Emodin enhances cytotoxicity of chemotherapeutic drugs in prostate cancer cells: The mechanisms involve ROS-mediated suppression of multidrug resistance and hypoxia inducible factor-1. Cancer Biol. Ther. 2008, 7, 468-475. [CrossRef] [PubMed]

44. Zhang, L.; Lau, Y.K.; Xia, W.; Hortobagyi, G.N.; Hung, M.C. Tyrosine kinase inhibitor emodin suppresses growth of HER-2/neu-overexpressing breast cancer cells in athymic mice and sensitizes these cells to the inhibitory effect of paclitaxel. Clin. Cancer Res. 1999, 5, 343-353. [PubMed]

45. Sallman, D.A.; Chen, X.; Zhong, B.; Gilvary, D.L.; Zhou, J.; Wei, S.; Djeu, J.Y. Clusterin mediates TRAIL resistance in prostate tumor cells. Mol. Cancer Ther. 2007, 6, 2938-2947. [CrossRef] [PubMed]

46. Ivanov, V.N.; Partridge, M.A.; Johnson, G.E.; Huang, S.X.; Zhou, H.; Hei, T.K. Resveratrol sensitizes melanomas to TRAIL through modulation of antiapoptotic gene expression. Exp. Cell Res. 2008, 314, 1163-1176. [CrossRef] [PubMed]

47. Shankar, S.; Chen, Q.; Siddiqui, I.; Sarva, K.; Srivastava, R.K. Sensitization of TRAIL-resistant LNCaP cells by resveratrol (3, 4', 5 tri-hydroxystilbene): Molecular mechanisms and therapeutic potential. J. Mol. Signal 2007. [CrossRef] [PubMed]

48. Jazirehi, A.R.; Bonavida, B. Resveratrol modifies the expression of apoptotic regulatory proteins and sensitizes non-Hodgkin's lymphoma and multiple myeloma cell lines to paclitaxel-induced apoptosis. Mol. Cancer Ther. 2004, 3, 71-84. [PubMed]

49. Quan, F.; Pan, C.; Ma, Q.; Zhang, S.; Yan, L. Reversal effect of resveratrol on multidrug resistance in KBv200 cell line. Biomed. Pharmacother. 2008, 62, 622-629. [CrossRef] [PubMed]

50. Rezk, Y.A.; Balulad, S.S.; Keller, R.S.; Bennett, J.A. Use of resveratrol to improve the effectiveness of cisplatin and doxorubicin: Study in human gynecologic cancer cell lines and in rodent heart. Am. J. Obstet Gynecol. 2006, 194, 23-26. [CrossRef] [PubMed]

51. Rigolio, R.; Miloso, M.; Nicolini, G.; Villa, D.; Scuteri, A.; Simone, M.; Tredici, G. Resveratrol interference with the cell cycle protects human neuroblastoma SH-SY5Y cell from paclitaxel-induced apoptosis. Neurochem. Int. 2005, 46, 205-211. [CrossRef] [PubMed]

52. Scarlatti, F.; Sala, G.; Ricci, C.; Maioli, C.; Milani, F.; Minella, M.; Botturi, M.; Ghidoni, R. Resveratrol sensitization of DU145 prostate cancer cells to ionizing radiation is associated to ceramide increase. Cancer Lett. 2007, 253, 124-130. [CrossRef] [PubMed] 
53. Pirzadeh, S.; Fakhari, S.; Jalili, A.; Mirzai, S.; Ghaderi, B.; Haghshenas, V. Glycyrrhetinic acid induces apoptosis in Leukemic HL60 cells through upregulating of CD95/ CD178. Int. J. Mol. Cell Med. 2014, 3, 272-278. [PubMed]

54. Jung, G.R.; Kim, K.J.; Choi, C.H.; Lee, T.B.; Han, S.I.; Han, H.K.; Lim, S.C. Effect of betulinic acid on anticancer drug-resistant colon cancer cells. Basic Clin. Pharmacol. Toxicol. 2007, 101, 277-285. [CrossRef] [PubMed]

55. Nabekura, T.; Hiroi, T.; Kawasaki, T.; Uwai, Y. Effects of natural nuclear factor-kappa B inhibitors on anticancer drug efflux transporter human P-glycoprotein. Biomed. Pharmacother. 2015, 70, 140-145. [CrossRef] [PubMed]

56. Suttana, W.; Mankhetkorn, S.; Poompimon, W.; Palagani, A.; Zhokhov, S.; Gerlo, S.; Haegeman, G.; Berghe, W.V. Differential chemosensitization of P-glycoprotein overexpressing K562/ Adr cells by withaferin A and Siamois polyphenols. Mol. Cancer 2010. [CrossRef] [PubMed]

57. Ikegawa, T.; Ushigome, F.; Koyabu, N.; Morimoto, S.; Shoyama, Y.; Naito, M.; Tsuruo, T.; Ohtani, H.; Sawada, Y. Inhibition of P-glycoprotein by orange juice components, polymethoxyflavones in adriamycin-resistant human myelogenous leukemia (K562/ADM) cells. Cancer Lett. 2000, 160, 21-28. [CrossRef]

58. Ikegawa, T.; Ohtani, H.; Koyabu, N.; Juichi, M.; Iwase, Y.; Ito, C.; Furukawa, H.; Naito, M.; Tsuruo, T.; Sawada, Y. Inhibition of P-glycoprotein by flavonoid derivatives in adriamycin-resistant human myelogenous leukemia (K562/ADM) cells. Cancer Lett. 2002, 177, 89-93. [CrossRef]

59. Mitsunaga, Y.; Takanaga, H.; Matsuo, H.; Naito, M.; Tsuruo, T.; Ohtani, H.; Sawada, Y. Effect of bioflavonoids on vincristine transport across blood-brain barrier. Eur. J. Pharmacol. 2000, 395, 193-201. [CrossRef]

60. Chieli, E.; Romiti, N.; Cervelli, F.; Tongiani, R. Effects of flavonols on Pglycoprotein activity in cultured rat hepatocytes. Life Sci. 1995, 57, 1741-1751. [CrossRef]

61. Shin, S.C.; Choi, J.S.; Li, X. Enhanced bioavailability of tamoxifen after oral administration of tamoxifen with quercetin in rats. Int. J. Pharm. 2006, 313, 144-149. [CrossRef] [PubMed]

62. Choi, J.S.; Jo, B.W.; Kim, Y.C. Enhanced paclitaxel bioavailability after oral administration of paclitaxel or prodrug to rats pretreated with quercetin. Eur. J. Pharm. Biopharm. 2004, 57, 313-318. [CrossRef] [PubMed]

63. Limtrakul, P.; Khantamat, O.; Pintha, K. Inhibition of P-glycoprotein function and expression by kaempferol and quercetin. J. Chemother. 2005, 17, 86-95. [CrossRef] [PubMed]

64. Sharma, V.; Joseph, C.; Ghosh, S.; Agarwal, A.; Mishra, M.K.; Sen, E. Kaempferol induces apoptosis in glioblastoma cells through oxidative stress. Mol. Cancer Ther. 2007, 6, 2544-2553. [CrossRef] [PubMed]

65. Wang, S.; Chen, R.; Zhong, Z.; Shi, Z.; Chen, M.; Wang, Y. Epigallocatechin-3-gallate potentiates the effect of curcumin in inducing growth inhibition and apoptosis of resistant breast cancer cells. Am. J. Chin. Med. 2014, 42, 1279-1300. [CrossRef] [PubMed]

66. Qian, F.; Wei, D.; Zhang, Q.; Yang, S. Modulation of P-glycoprotein function and reversal of multidrug resistance by (-)-epigallocatechin gallate in human cancer cells. Biomed. Pharmacother. 2005, 59, 64-69. [CrossRef] [PubMed]

67. Jodoin, J.; Demeule, M.; Beliveau, R. Inhibition of the multidrug resistance P-glycoprotein activity by green tea polyphenols. Biochim. Biophys. Acta 2002, 1542, 149-159. [CrossRef]

68. Castro, A.F.; Altenberg, G.A. Inhibition of drug transport by genistein in multidrugresistant cells expressing P-glycoprotein. Biochem. Pharmacol. 1997, 53, 89-93. [CrossRef]

69. Sak, K. Cytotoxicity of dietary flavonoids on different human cancer types. Pharmacogn. Rev. 2014, 8, 122-146. [CrossRef] [PubMed]

70. Luo, H.; Daddysman, M.K.; Rankin, G. O.; Jiang, B.H. Kaempferol enhances cisplatin's effect on ovarian cancer cells through promoting apoptosis caused by down regulation of cMyc. Cancer Cell Int. 2010. [CrossRef] [PubMed]

71. Piao, Y.; Shin, S.C.; Choi, J.S. Effects of oral kaempferol on the pharmacokinetics of tamoxifen and one of its metabolites, 4-hydroxytamoxifen, after oral administration of tamoxifen to rats. Biopharm. Drug Dispos. 2008, 29, 245-249. [CrossRef] [PubMed]

72. Chen, H.; Landen, C.N.; Li, Y.; Alvarez, R.D.; Tollefsbol, T.O. Epigallocatechin gallate and sulforaphane combination treatment induce apoptosis in paclitaxel-resistant ovarian cancer cells through hTERT and Bcl-2 down-regulation. Exp. Cell Res. 2013, 319, 697-706. [CrossRef] [PubMed] 
73. Luo, T.; Wang, J.; Yin, Y.; Hua, H.; Jing, J.; Sun, X.; Li, M.; Zhang, Y.; Jiang, Y. (-)-Epigallocatechin gallate sensitizes breast cancer cells to paclitaxel in a murine model of breast carcinoma. Breast Cancer Res. 2010. [CrossRef] [PubMed]

74. Park, S.; Kim, J.H.; Hwang, Y.I.; Jung, K.S.; Jang, Y.S.; Jang, S.H. Schedule-dependent effect of Epigallocatechin-3-Gallate (EGCG) with paclitaxel on H460 cells. Tuberc. Respir Dis. (Seoul) 2014, 76, 114-119. [CrossRef] [PubMed]

75. Rak, S.; Cimbora-Zovko, T.; Gajski, G.; Dubravčić, K.; Domijan, A.M.; Delaš, I.; Garaj-Vrhovac, V.; Batinić, D.; Sorić, J.; Osmak, M. Carboplatin resistant human laryngeal carcinoma cells are cross resistant to curcumin due to reduced curcumin accumulation. Toxicol. In Vitro 2013, 27, 523-532. [CrossRef] [PubMed]

76. Sreenivasan, S.; Krishnakumar, S. Synergistic effect of curcumin in combination with anticancer agents in human retinoblastoma cancer cell lines. Curr. Eye Res. 2015, 40, 1153-1165. [CrossRef] [PubMed]

77. Saha, S.; Adhikary, A.; Bhattacharyya, P.; Das, T.; Sa, G. Death by design: Where curcumin sensitizes drug-resistant tumours. Anticancer Res. 2012, 32, 2567-2584. [PubMed]

78. Cridge, B.J.; Larsen, L.; Rosengren, R.J. Curcumin and its derivatives in breast cancer: Current developments and potential for the treatment of drug-resistant cancers. Oncol. Discov. 2013. [CrossRef]

79. Ganta, S.; Amiji, M. Coadministration of Paclitaxel and curcumin in nanoemulsion formulations to overcome multidrug resistance in tumor cells. Mol. Pharmacol. 2009, 6, 928-939. [CrossRef] [PubMed]

80. Limtrakul, P.; Anuchapreeda, S.; Buddhasukh, D. Modulation of human multidrug-resistance MDR-1 gene by natural curcuminoids. BMC Cancer 2004. [CrossRef] [PubMed]

81. Anuchapreeda, S.; Leechanachai, P.; Smith, M.M.; Ambudkar, S.V.; Limtrakul, P.N. Modulation of P-glycoprotein expression and function by curcumin in multidrug-resistant human KB cells. Biochem. Pharmacol. 2002, 64, 573-578. [CrossRef]

82. Wang, P.; Yang, H.L.; Yang, Y.J.; Wang, L.; Lee, S.C. Overcome cancer cell drug resistance Using natural products. Evid. Based Complement. Alternat. Med. 2015. [CrossRef] [PubMed]

83. Yunos, N.M.; Beale, P.; Yu, J.Q.; Huq, F. Synergism from sequenced combinations of curcumin and epigallocatechin-3-gallate with cisplatin in the killing of human ovarian cancer cells. Anticancer Res. 2011, 31, 1131-1140. [PubMed]

84. Cromie, M.M.; Gao, W. Epigallocatechin-3-gallate enhances the therapeutic effects of leptomycin B on human lung cancer a549 cells. Oxid. Med. Cell Longev. 2015. [CrossRef] [PubMed]

85. Frampton, G.A.; Lazcano, E.A.; Li, H.; Mohamad, A.; DeMorrow, S. Resveratrol enhances the sensitivity of cholangiocarcinoma to chemotherapeutic agents. Lab. Invest. 2010, 90, 1325-1338. [CrossRef] [PubMed]

86. Lee, S.H.; Koo, B.S.; Park, S.Y.; Kim, Y.M. Anti-angiogenic effects of resveratrol in combination with 5-fluorouracil on B16 murine melanoma cells. Mol. Med. Rep. 2015, 12, 2777-2783. [CrossRef] [PubMed]

87. Kweon, S.H.; Song, J.H.; Kim, T.S. Resveratrol-mediated reversal of doxorubicin resistance in acute myeloid leukemia cells via downregulation of MRP1 expression. Biochem. Biophys. Res. Commun. 2010, 395, 104-110. [CrossRef] [PubMed]

88. Hsieh, T.C.; Wu, J.M. Resveratrol: Biological and pharmaceutical properties as anticancer molecule. Biofactors 2010, 36, 360-369. [CrossRef] [PubMed]

89. Cavaliere, V.; Papademetrio, D.L.; Lombardo, T.; Costantino, S.N.; Blanco, G.A.; Alvarez, E.M. Caffeic acid phenylethyl ester and MG132, two novel nonconventional chemotherapeutic agents, induce apoptosis of human leukemic cells by disrupting mitochondrial function. Target Oncol. 2014, 9, 25-42. [CrossRef] [PubMed]

90. Sugiyama, T.; Sadzuka, Y. Combination of theanine with doxorubicin inhibits hepatic metastasis of M5076 ovarian sarcoma. Clin. Cancer Res. 1999, 5, 413-416. [PubMed]

91. Liang, Y.R.; Liu, C.; Xiang, L.P.; Zheng, X.Q. Health Benefits of Theanine in Green Tea: A Review. Trop. J. Pharm. Res. 2015, 14, 1943-1949. [CrossRef]

92. Bhardwaj, R.K.; Glaeser, H.; Becquemont, L.; Klotz, U.; Gupta, S.K.; Fromm, M.F. Piperine, a major constituent of black pepper, inhibits human P-glycoprotein and CYP3A4. J. Pharmacol. Exp. Ther. 2002, 302, 645-650. [CrossRef] [PubMed]

93. Meral, O.; Alpay, M.; Kismali, G.; Kosova, F.; Cakir, D.U.; Pekcan, M.; Yigit, S.; Sel, T. Capsaicin inhibits cell proliferation by cytochrome c release in gastric cancer cells. Tumour Biol. 2014, 35, 6485-6492. [CrossRef] [PubMed] 
94. Xia, Q.; Wang, Z.Y.; Li, H.Q.; Diao, Y.T.; Li, X.L.; Cui, J.; Chen, X.L.; Li, H. Reversion of p-glycoprotein-mediated multidrug resistance in human leukemic cell line by diallyl trisulfide. Evid. Based Complement. Alternat. Med. 2012. [CrossRef] [PubMed]

95. Arora, A.; Seth, K.; Shukla, Y. Reversal of P-glycoprotein-mediated multidrug resistance by diallyl sulfide in K562 leukemic cells and in mouse liver. Carcinogenesis 2004, 25, 941-949. [CrossRef] [PubMed]

96. Rao, P.S.S.; Midde, N.M.; Miller, D.D.; Chauhan, S.; Kumar, A.; Kumar, S. Diallyl Sulfide: Potential Use in Novel Therapeutic Interventions in Alcohol, Drugs, and Disease Mediated Cellular Toxicity by Targeting Cytochrome P450 2E1. Curr. Drug Metab. 2015, 16, 486-503. [CrossRef] [PubMed]

97. Nabekura, T.; Yamaki, T.; Ueno, K.; Kitagawa, S. Inhibition of P-glycoprotein and multidrug resistance protein 1 by dietary phytochemicals. Cancer Chemother. Pharmacol. 2008, 62, 867-873. [CrossRef] [PubMed]

98. Nabekura, T. Overcoming multidrug resistance in human cancer cells by natural compounds. Toxins (Basel). 2010, 2, 1207-1224. [CrossRef] [PubMed]

99. Bueno Pérez, L.; Pan, L.; Sass, E.; Gupta, S.V.; Lehman, A.; Kinghorn, A.D.; Lucas, D.M. Potentiating effect of the flavonolignan (-)-hydnocarpin in combination with vincristine in a sensitive and P-gp-expressing acute lymphoblastic leukemia cell line. Phytother. Res. 2013, 27, 1735-1738. [CrossRef] [PubMed]

100. Febriansah, R.; Putri, D.D.; Sarmoko; Nurulita, N.A.; Meiyanto, E.; Nugroho, A.E. Hesperidin as a preventive resistance agent in MCF-7 breast cancer cells line resistance to doxorubicin. Asian Pac. J. Trop. Biomed. 2014, 4, 228-233. [CrossRef]

101. Nygren, P.; Glimelius, B. The Swedish Council on Technology assessment in Health Care (SBU) report on Cancer Chemotherapy--Project objectives, the working process, key definitions and general aspects on cancer trial methodology and interpretation. Acta Oncol. 2001, 40, 155-165. [PubMed]

102. Impicciatore, G.; Sancilio, S.; Miscia, S.; Di Pietro, R. Nutlins and ionizing radiation in cancer therapy. Curr. Pharm. Des. 2010, 16, 1427-1442. [CrossRef] [PubMed]

103. Sun, L.; Cabarcas, S.M.; Farrar, W.L. Radioresistance and Cancer Stem Cells: Survival of the Fittest. J. Carcinogene Mutagene 2011, 4172, 2157-2518.

104. Biard, D.S.; Martin, M.; Rhun, Y.L.; Duthu, A.; Lefaix, J.L.; May, P. Concomitant p53 gene mutation and increased radiosensitivity in rat lung embryo epithelial cells during neoplastic development. Cancer Res. 1994, 54, 3361-3364. [PubMed]

105. Sklar, M.D. The ras oncogene increases the intrinsic resistance of NIH $3 \mathrm{~T} 3$ cells to ionizing radiation. Science 1988, 239, 645-647. [CrossRef] [PubMed]

106. Kasid, U.; Pfeifer, A.; Weichselbaum, R.R.; Dritschilo, A.; Mark, G.E. The raf oncogene is associated with a radiation resistant human laryngeal cancer. Science 1987, 237, 1039-1041. [CrossRef] [PubMed]

107. Lee, J.U.; Hosotani, R.; Wada, M.; Doi, R.; Kosiba, T.; Fujimoto, K.; Miyamoto, Y.; Tsuji, S.; Nakajima, S.; Nishimura, Y.; et al. Role of bcl-2 family proteins (Bax, Bcl-2, Bcl-X) on cellular susceptibility to radiation in pancreatic cancer cells. Eur. J. Cancer 1999, 35, 1374-1380. [CrossRef]

108. Asanuma, K.; Moriai, R.; Yajima, T.; Yagihashi, A.; Yamada, M.; Kobayashi, D.; Watanabe, N. Survivin as a radioresistant factor in pancreatic cancer. Jpn. J. Cancer Res. 2000, 91, 1204-1209. [CrossRef] [PubMed]

109. Bao, S.; Wu, Q.; McLendon, R.E.; Hao, Y.; Shi, Q.; Hjelmeland, A.B.; Dewhirst, M.W.; Bigner, D.D.; Rich, J.N. Glioma stem cells promote radioresistance by preferential activation of the DNA damage response. Nature 2006, 444, 756-760. [CrossRef] [PubMed]

110. Zhang, S.; Wang, L.; Liu, H.; Zhao, G.; Ming, L. Enhancement of recombinant myricetin on the radiosensitivity of lung cancer A549 and H1299 cells. Diagn. Pathol. 2014. [CrossRef] [PubMed]

111. Sheehan, J.P.; Shaffrey, M.E.; Gupta, B.; Larner, J.; Rich, J.N.; Park, D.M. Improving the radiosensitivity of radioresistant and hypoxic glioblastoma. Future Oncol. 2010, 6, 1591-1601. [CrossRef] [PubMed]

112. Zhang, M.; Chakravarti, A. Novel radiationenhancing agents in malignant gliomas. Semin. Radiat. Oncol. 2006, 16, 29-37. [CrossRef] [PubMed]

113. Henriksson, R.; Malmstrom, A.; Bergstrom, P.; Bergh, G.; Trojanowski, T.; Andreasson, L.; Blomquist, E.; Jonsborg, S.; Edekling, T.; Salander, P.; et al. High-grade astrocytoma treated concomitantly with estramustine and radiotherapy. J. Neurooncol. 2006, 78, 321-326. [CrossRef] [PubMed]

114. Sartor, C.I. Mechanisms of disease: Radiosensitization by epidermal growth factor receptor inhibitors. Nat. Clin. Pract. Oncol. 2004, 1, 80-87. [CrossRef] [PubMed] 
115. Mehta, M.P.; Shapiro, W.R.; Phan, S.C.; Gervais, R.; Carrie, C.; Chabot, P.; Patchell, R.A.; Glantz, M.J.; Recht, L.; Langer, C.; et al. Motexafin gadolinium combined with prompt whole brain radiotherapy prolongs time to neurologic progression in non-small-cell lung cancer patients with brain metastases: Results of a Phase III trial. Int. J. Radiat. Oncol. Biol. Phys. 2009, 73, 1069-1076. [CrossRef] [PubMed]

116. Criswell, T.; Leskov, K.; Miyamoto, S.; Luo, G.; Boothman, D.A. Transcription factors activated in mammalian cells after clinically relevant doses of ionizing radiation. Oncogene 2003, 22, 5813-5827. [CrossRef] [PubMed]

117. Deorukhkar, A.; Krishnan, S.; Sethi, G.; Aggarwal, B.B. Back to basics: How natural products can provide the basis for new therapeutics. Expert Opin. Investig. Drugs 2007, 16, 1753-1773. [CrossRef] [PubMed]

118. Fabricant, D.S.; Farnsworth, N.R. The value of plants used in traditional medicine for drug discovery. Environ. Health Perspect. 2001, 109, 69-75. [CrossRef] [PubMed]

119. Donehower, R.C. The clinical development of paclitaxel: A successful collaboration of academia, industry and the National Cancer Institute. Stem Cells 1996, 14, 25-28. [CrossRef] [PubMed]

120. Shao, R.G.; Cao, C.X.; Zhang, H.; Kohn, K.W.; Wold, M.S.; Pommier, Y. Replication-mediated DNA damage by camptothecin induces phosphorylation of RPA by DNA-dependent protein kinase and dissociates RPA:DNA-PK complexes. EMBO J. 1999, 18, 1397-1406. [CrossRef] [PubMed]

121. Chen, Y.; Pandya, K.J.; Feins, R.; Johnstone, D.W.; Watson, T.; Keng, P.C. Toxicity profile and pharmacokinetic study of a phase I low-dose schedule-dependent radiosensitizing paclitaxel chemoradiation regimen for inoperable non-small-cell lung cancer. Int. J. Radiat. Oncol. Biol. Phys. 2008, 71, 407-413. [CrossRef] [PubMed]

122. Kurdoglu, B.; Cheong, N.; Guan, J.; Corn, B.W.; Curran, W.J., Jr.; Iliakis, G. Apoptosis as a predictor of paclitaxel-induced radiosensitization in human tumor cell lines. Clin. Cancer Res. 1999, 5, 2580-2587. [PubMed]

123. Girdhani, S.; Bhosle, S.M.; Thulsidas, S.A.; Kumar, A.; Mishra, K.P. Potential of radiosensitizing agents in cancer chemoradiotherapy. J. Cancer Res. Ther. 2005, 1, 129-131. [PubMed]

124. Arora, R.; Gupta, D.; Chawla, R.; Sagar, R.; Sharma, A.; Kumar, R.; Prasad, J.; Singh, S.; Samanta, N.; Sharma, R.K. Radioprotection by plant products: Present status and future prospects. Phytother. Res. 2005, 19, 1-22. [CrossRef] [PubMed]

125. Gault, N.; Lefaix, J.L. Infrared microspectroscopic characteristics of radiation-induced apoptosis in human lymphocytes. Radiat. Res. 2003, 160, 238-250. [CrossRef] [PubMed]

126. Hosseinimehr, S.J. Flavonoids and genomic instability induced by ionizing radiation. Drug Discov. Today 2010, 15, 907-918. [CrossRef] [PubMed]

127. Jebahi, S.; Saoudi, M.; Farhat, L.; Oudadesse, H.; Rebai, T.; Kabir, A.; El Feki, A.; Keskes, H. Effect of novel curcumin-encapsulated chitosan-bioglass drug on bone and skin repair after gamma radiation: Experimental study on a Wistar rat model. Cell Biochem. Funct. 2015, 33, 150-159. [CrossRef] [PubMed]

128. Rajendra Prasad, N.; Menon, V.P.; Vasudev, V.; Pugalendi, K.V. Radioprotective effect of sesamol on $\gamma$-radiation induced DNA damage, lipid peroxidation and antioxidants levels in cultured human lymphocytes. Toxicology 2005, 209, 225-235. [CrossRef] [PubMed]

129. Khan, S.; Kumar, A.; Adhikari, J.S.; Rizvi, M.A.; Chaudhury, N.K. Protective effect of sesamol against Co $\gamma$-ray-induced hematopoietic and gastrointestinal injury in C57BL/6 male mice. Free Radic. Res. 2015, 49, 1344-1361. [CrossRef] [PubMed]

130. Rajendra Prasad, N.; Srinivasan, M.; Pugalendi, K.V.; Menon, V.P. Protective effect of ferulic acid on $\gamma$-radiation-induced micronuclei, dicentric aberration and lipid peroxidation in human lymphocytes. Mutat. Res. 2006, 603, 129-134. [CrossRef] [PubMed]

131. Maurya, D.K.; Devasagayam, T.P. Ferulic acid inhibits gamma radiation-induced DNA strand breaks and enhances the survival of mice. Cancer Biother. Radiopharm. 2013, 28, 51-57. [CrossRef] [PubMed]

132. Sharma, N.K. Modulation of radiation-induced and mitomycin C-induced chromosome damage by apigenin in human lymphocytes in vitro. J. Radiat. Res. 2013, 54, 789-797. [CrossRef] [PubMed]

133. Rodeiro, I.; Delgado, R.; Garrido, G. Effects of a Mangifera indica L. stem bark extract and mangiferin on radiation-induced DNA damage in human lymphocytes and lymphoblastoid cells. Cell Prolif. 2014, 47, 48-55. [CrossRef] [PubMed]

134. Manna, K.; Das, U.; Das, D.; Kesh, S.B.; Khan, A.; Chakraborty, A.; Dey, S. Naringin inhibits gamma radiation-induced oxidative DNA damage and inflammation, by modulating p53 and NF- $\mathrm{kB}$ signaling pathways in murine splenocytes. Free Radic. Res. 2015, 49, 422-439. [CrossRef] [PubMed] 
135. Li, C.R.; Zhou, Z.; Zhu, S.; Sun, Y.N.; Dai, J.N.; Wang, S.Q. Protective effect of paeoniflorin on irradiation-induced cell damage involved in modulation of reactive oxygen species and the mitogen-activated protein kinases. Int. J. Biochem. Cell Biol. 2007, 39, 426-438. [CrossRef] [PubMed]

136. Yu, J.; Zhu, X.; Qi, X.; Che, J.; Cao, B. Paeoniflorin protects human EA.hy926 endothelial cells against gamma-radiation induced oxidative injury by activating the NF-E2-related factor 2/heme oxygenase-1 pathway. Toxicol Lett. 2013, 218, 224-234. [CrossRef] [PubMed]

137. Shimoi, K.; Masuda, S.; Shen, B.; Furugori, M.; Kinae, N. Radioprotective effects of antioxidative plant flavonoids in mice. Mutat. Res. 1996, 350, 153-161. [CrossRef]

138. Rahul, C.; Chatterjee, S.; Sharma, D.; Sumit, G.; Prasad, V.; Arun, S.; Poduval, T.B. Immunomodulatory and radioprotective effects of lignans derived from fresh nutmeg mace (Myristica fragrans) in mammalian splenocytes. Inter. Immunopharm. 2008, 8, 661-669.

139. Pradeep, K.; Ko, K.C.; Choi, M.H.; Kang, J.A.; Chung, Y.J.; Park, S.H. Protective effect of hesperidin, a citrus flavanoglycone, against $\gamma$-radiation-induced tissue damage in Sprague-Dawley rats. J. Med. Food. 2012, 15, 419-427. [CrossRef] [PubMed]

140. Gomes, C.C.; Ramos-Perez, F.M.; Perez, D.E.; Novaes, P.D.; Bóscolo, F.N.; Almeida, S.M. Radioprotective effect of vitamin E in parotid glands: A morphometric analysis in rats. Braz. Dent. J. 2013, 24, 183-187. [CrossRef] [PubMed]

141. Richi, B.; Kale, R.K.; Tiku, A.B. Radio-modulatory effects of green tea catechin EGCG on pBR322 plasmid DNA and murine splenocytes against gamma-radiation induced damage. Mutat. Res. 2012, 747, 62-70. [CrossRef] [PubMed]

142. Nayak, V.; Uma Devi, P. Protection of mouse bone marrow against radiation induced chromosome damage and stem cell death by the Ocimum Flavonoids orientin and vicenin. Radiat. Res. 2005, 163, 165-171. [CrossRef] [PubMed]

143. Ramadan, L.A.; Roushdy, H.M.; Abu Senna, G.M.; Amin, N.E.; EL-Deshw, O.A. Radioprotective effect of silymarin against radiation induced hepatotoxicity. Pharmacol. Res. 2002, 45, 447-454. [CrossRef] [PubMed]

144. Rao, B.N.; Archana, P.R.; Aithal, B.K.; Rao, B.S. Protective effect of Zingerone, a dietary compound against radiation induced genetic damage and apoptosis in human lymphocytes. Eur. J. Pharmacol. 2011, 657, 59-66. [CrossRef] [PubMed]

145. Patil, S.L.; Rao, N.B.; Somashekarappa, H.M.; Rajashekhar, K.P. Antigenotoxic potential of rutin and quercetin in Swiss mice exposed to gamma radiation. Biomed. J. 2014, 37, 305-313. [CrossRef] [PubMed]

146. Saada, H.N.; Rezk, R.G.; Eltahawy, N.A. Lycopene protects the structure of the small intestine against gamma-radiation-induced oxidative stress. Phytother. Res. 2010. [CrossRef] [PubMed]

147. Gandhi, N.M.; Maurya, D.K.; Salvi, V.; Kapoor, S.; Mukherjee, T.; Nair, C.K.K. Radioprotection of DNA by glycyrrhizic acid through scavenging free radicals. J. Radiat. Res. 2004, 45, 461-468. [CrossRef] [PubMed]

148. Jagetia, G.C.; Venkatesha, V.A. Treatment of mice with stem bark extract of Aphanamixis polystachya reduces radiation-induced chromosome damage. Int. J. Radiat. Biol. 2006, 82, 197-209. [CrossRef] [PubMed]

149. Zbikowska, H.M.; Antosik, A.; Szejk, M.; Bijak, M.; Nowak, P. A moderate protective effect of quercetin against $\gamma$-irradiation-and storage-induced oxidative damage in red blood cells for transfusion. Int. J. Radiat. Biol. 2014, 90, 1201-1210. [CrossRef] [PubMed]

150. Zhang, R.; Kang, K.A.; Kang, S.S.; Park, J.W.; Hyun, J.W. Morin (2',3,4',5,7-pentahydroxyflavone) protected cells against $\gamma$-radiation-induced oxidative stress. Basic Clin. Pharmacol. Toxicol. 2011, 108, 63-72. [CrossRef] [PubMed]

151. Parihar, V.K.; Dhawan, J.; Kumar, S.; Manjula, S.N.; Subramanian, G.; Unnikrishnan, M.K.; Rao, C.M. Free radical scavenging and radioprotective activity of dehydrozingerone against whole body gamma irradiation in Swiss albino mice. Chem. Biol. Interact. 2007, 170, 49-58. [CrossRef] [PubMed]

152. Mozdarani, H.; Ghoraeian, P. Modulation of gamma-ray-induced apoptosis in human peripheral blood leukocytes by famotidine and vitamin C. Mutat. Res. 2008, 649, 71-78. [CrossRef] [PubMed]

153. Burlage, F.R.; Roesink, J.M.; Faber, H.; Vissink, A.; Langendijk, J.A.; Kampinga, H.H.; Coppes, R.P. Optimum dose range for the amelioration of long term radiation-induced hyposalivation using prophylactic pilocarpine treatment. Radiother. Oncol. 2008, 86, 347-353. [CrossRef] [PubMed] 
154. Cho, J.H.; Hong, W.G.; Jung, Y.J.; Lee, J.; Lee, E.; Hwang, S.G.; Um, H.D.; Park, J.K. Г-Ionizing radiation-induced activation of the EGFR-p38/ERK-STAT3/CREB-1-EMT pathway promotes the migration/invasion of non-small cell lung cancer cells and is inhibited by podophyllotoxin acetate. Tumour Biol. 2015. [CrossRef] [PubMed]

155. Zhang, W.; Anker, L.; Law, R.E.; Hinton, D.R.; Gopalakrishna, R.; Pu, Q.; Gundimeda, U.; Weiss, M.H.; Couldwell, W.T. Enhancement of radiosensitivity in human malignant glioma cells by hypericin in vitro. Clin. Cancer Res. 1996, 2, 843-846. [PubMed]

156. You, H.; Wei, L.; Sun, W.L.; Wang, L.; Yang, Z.L.; Liu, Y.; Zheng, K.; Wang, Y.; Zhang, W.J. The green tea extract epigallocatechin-3-gallate inhibits irradiation-induced pulmonary fibrosis in adult rats. Int. J. Mol. Med. 2014, 34, 92-102. [CrossRef] [PubMed]

157. Byun, E.B.; Sung, N.Y.; Park, J.N.; Yang, M.S.; Park, S.H.; Byun, E.H. Gamma-irradiated resveratrol negatively regulates LPS-induced MAPK and NF-KB signaling through TLR4 in macrophages. Int. Immunopharmacol. 2015, 25, 249-259. [CrossRef] [PubMed]

158. Seong, K.M.; Yu, M.; Lee, K.S.; Park, S.; Jin, Y.W.; Min, K.J. Curcumin mitigates accelerated aging after irradiation in Drosophila by reducing oxidative stress. Biomed Res. Int. 2015. [CrossRef] [PubMed]

159. Kasten-Pisula, U.; Windhorst, S.; Dahm-Daphi, J.; Mayr, G.; Dikomey, E. Radiosensitization of tumour cell lines by the polyphenol Gossypol results from depressed double-strand break repair and not from enhanced apoptosis. Mol. Radiobiol. 2007, 83, 296-303. [CrossRef] [PubMed]

160. Bache, M.; Zschornak, M.P.; Passin, S.; Kessler, J.; Wichmann, H.; Kappler, M.; Paschke, R.; Kaluđerović, G.N.; Kommera, H.; Taubert, H.; et al. Increased betulinic acid induced cytotoxicity and radiosensitivity in glioma cells under hypoxic conditions. Radiat. Oncol. 2011. [CrossRef] [PubMed]

161. Nair, S.; Nair, R.R.; Srinivas, P.; Srinivas, G.; Pillai, M.R. Radiosensitizing Effects of Plumbagin in Cervical Cancer Cells Is Through Modulation of Apoptotic Pathway. Mol. Carcinog. 2008, 47, 22-33. [CrossRef] [PubMed]

162. Yang, E.S.L.; Choi, M.J.; Kim, J.H.; Choi, K.S.; Kwon, T.K. Withaferin A enhances radiation-induced apoptosis in Caki cells through induction of reactive oxygen species, Bcl-2 downregulation and Akt inhibition. Chem. Biol. Interact. 2011, 190, 9-15. [CrossRef] [PubMed]

163. Bhoslea, S.M.; Huilgola, N.G.; Mishra, K.P. Enhancement of radiation-induced oxidative stress and cytotoxicity in tumor cells by ellagic acid. Clin. Chim. Acta 2005, 359, 89-100. [CrossRef] [PubMed]

164. Mansour, H.H.; Tawfik, S.S. Early treatment of radiation-induced heart damage in rats by caffeic acid phenethyl ester. Eur. J. Pharmacol. 2012, 692, 46-51. [CrossRef] [PubMed]

165. Kim, I.G.; Kim, J.S.; Lee, J.H.; Cho, E.W. Genistein decreases cellular redox potential, partially suppresses cell growth in HL-60 leukemia cells and sensitizes cells to $\gamma$-radiation-induced cell death. Mol. Med. Rep. 2014, 10, 2786-2792. [CrossRef] [PubMed]

166. Puthli, A.; Tiwari, R.; Mishra, K.P. Biochanin A enhances the radiotoxicity in colon tumor cells in vitro. J. Environ. Pathol. Toxicol. Oncol. 2013, 32, 189-203. [CrossRef] [PubMed]

167. Venier, N.A.; Colquhoun, A.J.; Sasaki, H.; Kiss, A.; Sugar, L.; Adomat, H.; Fleshner, N.E.; Klotz, L.H.; Venkateswaran, V. Capsaicin enhances the effect of radiation in prostate cancer through NF-kB suppression. Cancer Res. 2013. [CrossRef]

168. Tak, J.K.; Lee, J.H.; Park, J.W. Resveratrol and piperine enhance radiosensitivity of tumor cells. BMB Rep. 2012, 45, 242-246. [CrossRef] [PubMed]

169. Jin, Y.; Lyu, Y.; Tang, X.; Zhang, Y.; Chen, J.; Zheng, D.; Liang, Y. Lupeol enhances radiosensitivity of human hepatocellular carcinoma cell line SMMC-7721 in vitro and in vivo. Int. J. Radiat. Biol. 2015, 91, 202-208. [CrossRef] [PubMed]

170. Wang, J.; Yu, M.; Xiao, L.; Xu, S.; Yi, Q.; Jin, W. Radiosensitizing effect of oleanolic acid on tumor cells through the inhibition of GSH synthesis in vitro. Oncol. Rep. 2013, 30, 917-924. [PubMed]

(C) 2016 by the authors; licensee MDPI, Basel, Switzerland. This article is an open access article distributed under the terms and conditions of the Creative Commons by Attribution (CC-BY) license (http:/ / creativecommons.org/licenses/by/4.0/). 